др Слободан Грубачић

проф. емеритус

Универзитет у Београду

Филолошки факултет

https://doi.org/10.18485/ai_san_o_gradu.2018.ch1

\title{
САН О ГРАДУ
}

\section{РЕТРОСПЕКТИВНЕ УТОПИЈЕ У КЬИЖЕВНОСТИ}

1.

Град је миљеник утопије. Измаштан али не мање стваран, он није уписан у књигама земљомерним као ни друге творевине човековог ума, од поезије до математике. У вишеградском Каменграду, том постмодерном утврђењу као предграђу реалне утопије, „хетеротопије“, све ведуте израстају из историјских фантазама. Чувају одлике битне за архитектуру пасажа и перспективе, за доколицу шетача као интелектуалног номада, за естетски шок као начело перцепције. Утопијски сјај бледи тек у мери у којој култура сећања нуди нови реализам: непосредни доживљај и духовни узлет. Епифанија вреба овде иза сваког угла - као што сваки град има свој „дух места“ који може да рефлектује универзум, цео свет, као што је сваки полис имао агору, и као што је средњовековно село имало цркву за своје средиште, место где се људи окупљају тражећи разговор, утеху или просветљење.

Андрићград није ни село ни метропола. Он је метафора, сан. Магија овог каменог, урбаног симбола још увек није довољно уочена. Постоје локалитети, места која имају своју судбину, своју чаролију, слично алитерацији чији магијски звучни ефекат нас враћа у детињство језика, у доба ране примене гласовног симболизма, 
када глас није било могуће одвојити од акције - када се „град градио“, кад је „збор зборио“ а „звоно звонило“. Лако се, притом, успоставља његова сакрална топографија, као и она профана. Није тајна да шароликост ове топографије, саздане од свесно секундарних, цитатних облика, доживљавамо као мозаик разнородних делова.

Но, ако се најпознатији цитат многих европских извора, архитектура Санкт Петербурга, заснива, како сматра Михаил Епштејн, на поетици секундарности, другостепености; ако је њена поетика изведена из $\bar{u} y \hbar e \bar{\imath}$, западноевропског наслеђа - онда је Андрићград цитат, тачније: свод цитата који своју нескривену другостепеност изводи из сойсиивено, оригиналног духовног наслеђа, стварајући једну наизглед немогућу синтезу. Осим простора, згушњава се и време: амалгам, укрштај шароликог света мохамеданске, католичке и ортодоксне конфесије, у коме се бројне цивилизацијске одлике развијају асинхроно, а опет много сјајније, много маркантније и - много несрећније него у другим европским земљама, помаља се, лудистички умањен. Цео макрокосмос је смештен у камени микрокосмос.

Па ипак, он је много мање лексикон балканског живота, а много више енциклопедија књижевносиии. Поникла на богатој фолклористичкој, етимолошкој, етнографској, археолошкој, историјској, географској литератури, ugeja iрpaga представља, у овом случају, антрополошко-поетичку визију јединственог „урбаног ансамбла“ - визију пониклу из ауторовог трагања за историјском основом самог појма іраg и његовим усклађивањем са тако званим „објективним налазом“ у епској литератури.

Видећемо да њени темељи нису само у дубинама реке Дрине, у каменом подножју моста којим су прошле најезде и крвопролића, луталице и грађани света, 
али и весници крупних духовних преображаја који још живе у предању и песничким текстовима. Утолико се Кустуричин ауторски печат не може копирати нити следити, него само читати, будући да симболизује онај степен универзализације искуства коју доноси укрштај разноликих културних утицаја. Његов је наратив старији од њега самога: он је безвремен, јер сведочи о $y p \delta o-$

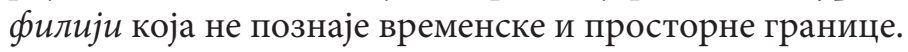

Ако се, полазећи од репрезентативног корпуса, као што је то учинила Мирјана Детелић у драгоценој књизи Ейски ірраgови, ${ }^{1}$ упоредо посматра хришћанска и муслиманска епска поезија - која, будући на истом језику, од претходне преузима поетску граматику, без обзира на идеолошке и верске разлике условљене историјским околностима - намеће се закључак да обе имају не само заједничке ојкониме, већ се „за град везују исти епитети и заједничка атрибуција“ - двоструко више пута у односу на село. Тако представе о бројним градовима којима се епика бави, у потпуности мењају слику о њеној поезији као руралној. За то постоји и додатно објашњење. Како се моћ и снага државе изједначава са „бројем и снагом градова који је чине“, постаје јасно зашто епска песма са својим изразитим идеолошким обележјима - видећи у граду центар власти, државне, духовне и политичке - градове стављала у средиште својих занимања.

„Судбина и коментари“ њиховог настајања, рушења, реконструисања, и новог настајања у смени цивилизација, историјских, друштвених и културних збивања, повезани су, званично, са судбином њихових господара. Тек је мален број путника и намерника, странаца и „перегрина“, свестан да је и њихова сопстве-

1 Детелић, М.: Ейски їраgови, Београд 2007. 
на судбина последња блага успомена у срцу жестоко разједињеног новог света. Почели су, говорио је Зоран Мишић, да траже себе у огледалу једног света коме прети да самог себе више не препозна. Давно је посведочено: у превеликој журби да се приближимо европској култури, заборавили смо и ми да наша традиција чини део те културе.

Андрићград је симбол епскога града насталог из меморије огромног простора који су захватале велике империје од медитеранског и црноморског басена, допирући на запад до Лондона, на исток до Азова, на север до Беча, све до Петрограда, а ми представљали сре-

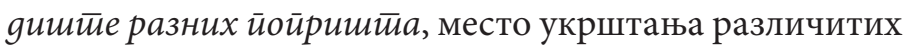
вера, раскрсницу путева - збир крајина. Он реконструише, као да избавља из пожара, цео „каталог“ архитектонских, просторних и културних елемената. То је смисао његове монтаже, али у једнаком опсегу подразумева сећање на боравишта прогутана и засута на плодним обалама. На пожаре који су гутали најстарија светишта. На становнике који нису имали непријатеља - изневерене захваљујући пријатељима.

Када би и сам Каменград био слика, био би то велики мурал на коме - приказујући десетине ликова и ситуација - аутор сигурном руком довршава слику „Босна у прошлости и садашњости“. То је покушај да се, када нам свима прети виртуелно време, управо на таквој слици, амбивалентној и накрцаној искуством, у пуној мери, па и преко свих очекивања, потврди кохерентност визије и интерпретативне пројекције наше заједничке прошлости.

Њена дефиниција звучи као афоризам: раније је све било касније, свака прошлост је пролог. А за ту визију су способни тек малобројни. Не може бити случајно што је умни Валтер Бењамин, испред свог чуве- 
ног огледа Париз, ӥресиионица 19. века, као мото ставио речи Максима Дикама: „Историја је попут Јануса: има два лица, свеједно је да ли гледа прошлост или садашњост, увек види исто“.2

Стога се целокупна повест „претаче“ у јединствени простор, у поприште догађаја. Као у свету Хермана Минковског, обележја времена су у простору, а простор је тачка у којој се спајају прошлост и садашњост. Можда је израз „панорамски“ најпогоднији да означи схватање повести у кључу градитеља. Јер, ако је историја преточена у простор, у место збивања, у онај нуминозни питагорејски сједињени простор, онда је то израз исте метафизичке тенденције која је својевремено у егзактној науци водила ка инфинитезималном рачуну. У оба случаја се процес кретања времена схвата у једној „опростореној“с слици и анализира.

Градитељу, међутим, није стало да пропорције сведе на антички златини ӣресек. Напротив. Камени „страдунски“ плочник представљен је као палимпсест преко којег су мапе епоха̂ пребачене једна преко друге. Та слика „места радње“, тачније, тај убрзани ход кроз балканску имагологију одговара протицању воде испод каменог моста, те тако и дух судбинске и временске пролазности постаје кључ за разумевање архетипско-наративног споја: Камени мост и Каменград дејствују као два магнета који теже стварању амалгама - заједничког историјског простора путем културе визуелног.

Супротно континуираном протицању, слика Андрићграда се распрскава у разиграност простора коју бисмо смели назвати кореоірафском. Дискурзивна формација је изврнута, измештена, театрализована.

2 L'histoire est comme Janus, elle a deux visages: qu'elle regarde le passé ou le présent, elle voit les mêmes choses (Maxime Du Camp, Paris. VI, p. 315). 
А на питање ко је организатор њених заплета, лако је дати одговор. То је наративни сукцесор позоришних и филмских сценских мајстора - писац коме је смрт „непровјерена гласина“, и коме се очигледно чини да ће кипови и слике закорачити, зидови проговорити, да ће из околне воде што протиче као зеленкасто, потамнело огледало, изненада доћи пророштво.

Обале Дрине нису обале Лете, чије име значи $3 a-$ $\delta о р а в$, па се то пророштво јавља и као утопијски дискурс у интеркултурном контексту. Град је за пројекцију утопије идеалан, јер нуди могућу кохабитацију у животном простору који су изградили људи. Знамо да од њега, те државе у минијатури, тог каменог оквира сваке утопије, нема инспиративније визије. То је оно што артикулише и микрологију овог града. У њој васкрсава невероватан благослов, блаїослов gеминуйива који допушта да се велико наслути у сићушном, силовито у најинтимнијем, мит у бајци - благослов утопије. А она би да оствари идеал заједнице у којој нико неће другоме наметати сойсиивену идеју утопије.

Будући остварена утопија, простор Каменграда

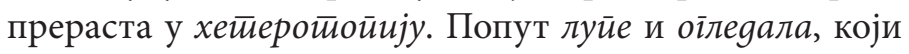
су доминирали у ранијим теоријама, она у савременој типологији заузима занимљиво место. Осим упадљиве дислокације која одликује ову врсту хетеротопије, у истом знаку стоје појмови раскида, прага, капије, границе и зида. Не само због тога што, као „место изван сваког места“ (Фуко) $)^{3}$, представља контрастну слику и својеврсно перфекционирање постојећег света. Него по томе што, захваљујући оптичкој концентрацији, укључује амалгам куличурних стилова и хетерогеност реалних простора. Што може бити перципиран у „вре-

3 M. Foucault, Andere Räume, Frankf. 1967, str. 39. 
менској расутости“, где бива понављан, изнова сазнат и преображен, позициониран између имагинарног и реалног, прошлог и будућег.

И док је то код нас, посматрајући ствари дијахроно, захваљујући месту на коме се налазимо, већ био случај са варијантама романике и готике, са византинизмом или фрушкогорским бароком, код других се остваривао у другачијој призми у слици традиционалног „персијског врта“, чији микрокосмос симболично одсликава цео свет, а поређење је могуће и са затвореном биоскопском салом која у исти мах отвара прозор у неке друге светове. Особеност се, најзад, огледа о у томе што је све подређено неком интерном начелу реда и поретка. Реда који се супротставља претпостављеном „општем нереду“. То је, најкраће речено, својеврсни $\bar{u}$ ростиор комиензације - остварена утопија која се, по својој основној замисли, појављује као модел „савршенијег“" реалног простора. И који притом и сам компензује Русоов појам perfectibilité.

2.

Као да је целокупна историја утопијаิ симболично сажета у судбини светогорског монаха из 14. века Јована Палигорца, који је сам градио, а потом уништавао мале капеле и црквице по Светој Гори, оличавајући сушту религиозност човека, по мисли водиљи: „Нађи Бога, уништи га и тражи поново“. Тај вечни сан о ірpagy, та скривена димензија огромне снаге којом је прожета утопија, то није нека Ламартинова „пре-времена истина“. Није ни потврда оне безличне дефиниције по којој утопија као „не-место“ нуди „друго место наместо овог места“. То је чежњиви сан сетних и смерних, сан који се рађа у најскривенијој радионици душе где и сањалице 
имају чврсто тло под ногама, само што су ипак ближе звездама док узвикују: Утопију нашу насушну дај нам данас!

Јер, будимо реални: ми смо у души тако дубоко анархистички надахнути, да нам се живот чини вредним само у утопији. У исти мах смо толико цинични, да нам се она чини уверљивом само кад је ауторитарна. Свака утопија је маскирана дистопија. Уколико у актуелном друштву види негацију могућег бољег света, она је неїација неїације. Деструкција прелази у конструкцију. А као конструкт секуларизованог ума, она је нормативно окренута „светлој будућности“ кроз пројекцију фиктивног сценарија једног идеалног друштва. ${ }^{4}$ Или прецизније: кроз пројекцију једне утопије која неће постати Атлантида.

Али када се тај другачији свет, тај идеални alter mundus, извргне у своју супротност; када те новостворене структуре моћи произведу нежељене или кобне последице које нас држе у пометњи, на путу напредујућег отуђења и трајног заборава бића; када се, конкретно, Платонова најбоља држава преметне у йиранugy - утопијска мисао се мора запитати зашйо је пут у пакао понекад поплочан добрим утопијским намерама. Мора преиспитати своје битне претпоставке, па тако и оправданост литерарног заснивања једне „теорије утопијског прорицања“.

Али са̂м интенционални појам утопије, теоријски утемељен код Ландауера и разрађен код Манхајма и Блоха, сувише је широк. Када данас читамо њихове списе који су им за живота прибавили филозофске ореоле,

4 Richard Saage, Wie zukunftsfähig ist der klassische Utopiebegriff? In: Utopie kreativ, H. 165/166 (Juli/August 2004), S. 623. 
примећујемо да више немају ону оштрину увида која би премерила сав распон савремених урбаних визија и жеља, снова и разочарења. Један од лако доказивих уз-

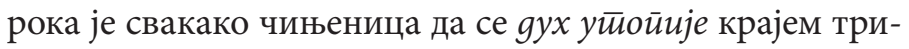
десетих година прошлог века нагло политички радикализово. Други узрок још мање подлеже сумњи. Треба га потражити у отпору модерног човека према класичним утопијама као могућности сопственог ослобођења.

Некеда је све изгледало једноставније: човечанство је видело три пута према далеком циљу. Први је водио у одрицање, у бекство од света, други пут је био пут његовог поправљања. Трећи је био утопијски сан који, неретко, претвара чежњу за лепшим животом у уметничке облике. Данас је из више разлога потребно унети јасне дистинкције у цели тај стратешки фронт. Неопходне су нијансиране раздеобе између несавршене реалности и савршенства замисли, пре свега у основној дихотомији која постоји између два наратива - између утопијског наратива као „романа“ (у чијем средишту је стање које треба остварити) и рационалног „акционог програма“ (који више приказује пут него циљ).

На епском порталу утопије разазнају се, каткад неупадљиво али сасвим извесно, њене кључне одреднице. Најпре су то одреднице жанра („аркадија“, „краљевско пророчанство“, „робинзонада"), потом моgела („анархија“, „монархија“) и књижевног облика („памфлет“, „молитва“, „програм“), и, коначно, йенgениије („реформистички“, „конзервативно“, „револуционарно“).

Старија од свог имена, утопијска мисао од памтивека критикује реални свет из угла моїућеї света. Утопија је појам чежње који се заснива на очигледним недостацима постојећег. Сан који уклања постојећу беживотност. Потврђујући Шпенглеров став да је исйорија іраga

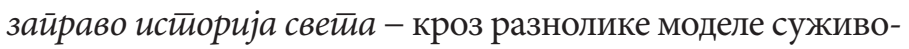


та, од прастарих оријенталних урбаноморфних „мандала“ и визија „велике колевке“, преко ренесансних „простора cреће“ и блаженог града (urbs beata) - она повремено доспева до танано-медитативних и интелектуално-схоластичких варијација, па и до „екистичких прогноза“ једног Константина Доксијадиса.

Иако се повод за настанак утопије крије у критици друштва, њен облик се испољава као контрафактура града: социјална утопија постаје урбана. Идеални градови барока и ренесансе заправо и не конкретизују утопију, они су чиста форма, нарочито где је у првом плану фортификација. Уколико се не своде на рационалну спроводљивост као у новим насеобинама у прекоморским земљама, обе утопије, социјална и урбана, оличавају својеврсни креационизам: доминантне у нашој свести, нераскидиво повезане, оне рефлектују „поредак идеја“. Као „велике нарације“, оне симболизују поглед на свет - конкретизују апстрактну представу о природи, свету и васиони.

Utopia, осим тога, остаје изолована и непроменљива. Њен слободни простор није слободан у правом смислу речи. Недостаје онај ирационални маневарски простор који доноси промене, а то, опет, за собом повлачи борбу и неправду. Та противречност раскрива целу упитност утопије оличену у идеалу и нади, инспирацији и подстицају, у сну о земаљској срећи, у коме све личи на свет у кристалној кугли, просветљен изнутра. Људи су замрзнути, заробљени у бајковитом свету и сијају на ружичастој позадини сцене као осветљени изнутра. Фантоми меланхолије и лепоте лутају неким холом с огледалима без краја. Остварена утопија доноси стагнацију и досаду, у најмањују руку: успвљујући комфор, како су тврдили велики мислиоци, од Аристотела до Хегела.

Другим речима, уколико би заиста постигла циљ, то би значило да су људи негде учинили омашку, испусти- 


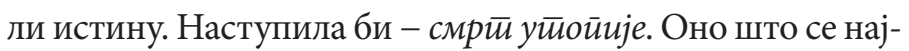
мање очекује. У томе се понавља аналогија с друштвеним превратима: када постану режим и поредак, револуције се компромитују. „Револуције су као Сатурн”, изговара сетно револуционар Жорж Дантон у чувеној Бихнеровој драми као наговештај сопствене насилне смрти: „Оне једу своју сопствену децу” - попут магличасте, небуларне планете чије сателите су растргле њене „плимне силе”. Драматичар Ежен Јонеско, аутор Краља који умире, утемељитељ театра апсурда, заштрио је ову аналогију до крајности тврдећи да је буржуј, „становник града”, највећи корисник Револуције из 1789. године, постао „неупоредиво гнуснији” од племства у осамнаестом веку.

„Наш живот сања утопију, наша смрт је доводи до краја“, написао је Виктор Иго у својој Иниеелекииуалној ауйобиоірафији, мада - треба и то рећи - књижевно инсценирани суживот на парадоксални начин траје и даље. Не само у наивној машти и представама непоправљивих занесењака. Супротно постмодерним најавама „краја велике нарације”, дуговеки „ланас утопија” (Орвел) није прекинут. Свет је постао сувише опасан да би се лишио утопије. Он напросто не може без илузије, упркос вечном страху од њених остварења.

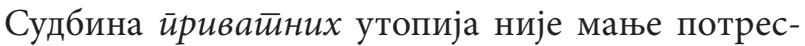
на. Бројни су они који живот без утопије сматрају само генералном пробом пред смрт. Када Леопарди каже да „сањано уживање вреди исто колико и стварно”, тада се с правом може рећи да „онај ко пише не сме истовремено да сања”. Није стога необично што су утопија и меланхолија две стране исте медаље на којој се лице и наличје све мање разликују. Још мање чуди што је утопијска заједница углавном имала облик града-државе чије зидине симболизују и слободу и изолацију. Оне у исти мах спајају и раздвајају конкретно и апстрактно, стварно и могуће. 
Једнако је широк и разуђен регистар оних нереалних модела ишчекиваға обухваћених термином $ф u-$ іуре уйойије. Једни се „боре за светлу прошлост“, за повратак старим вредностима у себе загледаног полиса, за преокретање времена и обнову Кроновог „златног доба“ похрањеног негде између сећања и замишљања. За друге, ствари стоје другачије. Небо је у висини. Утопија је овgе. Спокојство је саga. Нирвана је $\bar{w} y$.

Трећи верују у „прицип наде“, у срећну звезду и озарени сан о Нигдини, потиснутој у неко бајковито подручје, где ништа није по себи разумљиво, осим чуда, у које сами више не верују. Временско некаg одговара просторном неїgе. То је, у суштини, просветитељска бајка о победи пристојности и доброте. Јер само сањарски, вођени логиком сна, само тако могу да наслуте егзистенцију тог простора, који је заправо њихов сопствени, па чак и тада једва да доспевају даље од његове улазне капије.

Најлепши симбол „поезије од камена“, Венеција, постоји додуше још увек, али због своје посебне топографије и даље делује нестварно - толико, да њена патина и њен $c \oint y м а \bar{и} о$ имају функцију инструмента у јединственом „пројекту самокреације“: у пројекту стапања с околином, у преливању у коме нестаје разлика између предела и људског лика - готово на начин проласка кроз осликани зид. И ми се питамо: да ли је то онај степен „остварене утопије“, она тачка на којој се венчавају сан и јава - тачка преокрета на којој би текстови Шатобријана хтели да укину све противречности? Или је то - супротно - она тачка утопије на којој Емил Сиоран види сукоб опојне, сакралне естетике и рационалне световности, помало инфантилне и анђеоски наивне, место где текстови Баре́а - „Ако Венеција умре, умреће и идеја града...“, али и снови Пола Мора- 
на о „палатама које пате што нису бродови“ - показују како Венеција постаје семиотички простор по чијој мери се реконструише, ${ }^{5}$ гра̂ди личност самог аутора?

Док спрема одговар на та питања, посматрајући свој предмет, сама мисао у највишем, екстатичном тренутку посматра и себе саму. Јер, процес гледања и однос чулног сазнања према мишљењу објашњава се једноставно - (ре)конструкцијом ауторових менталних топоса. Он се препушта некој врсти „просторног мишљења“: преиспитује свој идентитет и мапира простор кроз димензију афекта, откривајући себе као чулно соматско биће. Висока ренесанса је већ размишљана на тој основи. Чинквеченто је, каже Велфлин, „имао нарочито снажно осећање за однос између човека и грађевине, за резонанцу лепог простора. Готово да се не може замислити његово постојање без архитектонског израза и утемељења". вамо тело предмета које посматрамо. Бивство града није скривено у натчулним, метафизичким суштинама, већ је физички присутно, исијава као твар. Јаче од фотографије, од тог „огледала које се сећа“.

Штавише, утисцима пропадања, урушавања, расула које се попут плесни шири окружењем, заједничко је што дејствују као - естиетиска вреgности. Код њене пријемчивости посматрач се разликује од Лазе Костића и његовог венецијанског доживљаја. Не пита да ли је његова сублимациона снага заиста дорасла призору који му се нуди. Он пројицира естетску димензију у подручје градске утопије. У томе види радикално нов

5 H. Hufnagel, Glück in Venedig. Ausformungen einer utopischen Chiffre bei französischen Konservativen: Chateaubriand, Barrès, Morand, in: B. Ventarola, Literarische Stadtutopien zwischen totalitärer Gewalt und Ästhetisierung. München 2011. S. 155.

6 Heinrich Wölflin, Die klassische Kunst, München 1899, 277. 
естетски став, који подразумева успостављање урбанитета као уметничког дела. И док у исти мах лепота еманира из зачараног града, из града који живи своје нестајање, посматрач бива свестан, и све свеснији, и с тим сетнији, да су наоко супротни феномени међусобно повезани.

Естетика утопије је, овде, једна поетика перцепције. Ова врста чулног сазнања је притом јасна, али не и разговетна: рационалност се повлачи пред изворном тајном лепоте. Стога сагласност опажања чулних датости рађа трептаје попут музике коју емитује инструмент или коју еманира уметничка слика. И ако посматрач има тај сензибилитет, ако осећа те трептаје, он ће тако доживети и слику града и њену енергију. Чак и кад искидана динамика и судар стилова заустављају дах.

Све се онда мења: куће имају људске изразе, град што замишљено посматра своју сенку у тамној води постаје његов двојник, његово друго Ја, тако да и њихова љубав „на први поглед“ открива да град није само кулиса и хладни камени омотач друштвеног система. Он је и начин осећања који даје смисао физичком сценарију, који се каткад претвара у епифанијски тренутак, у магновено озарење. У један облик наизглед утихле екстазе који би у свему, где год би могао, а могао је свугде, до краја изменио и иррозне іримасе приповедача, кога с мимичком непосредношћу редом, буквално, спопадају сви утисци.

Има их у маниризму и раскошном језичком дискурсу који одговарају украсима чипкастих фасада, има у опсесији лепотом - одликама које би да савладају, удоме у себи, опажену, осетима препознату лавиринтску топографију чудесног града. Ту постаје значајна тврдња да су и људска бића „културни артефакти”, да је култура пресудна у одређивању људске природе. Такво искуство је богато значењима: она није само надградња 
у одређивању људске природе. Није ни пуки надоместак за рђаву стварност у име могућности да естетика постане ново „начело ствраности”. Она узима примордијално искуство изворног опажања као основу свеколиког сазнања. Чак је и марксиста Лукач у својој Eстиетиици (I, 2), говорећи о градовима и здањима које изазивају емоције својом непосредном појавом, указивао на чудновату „поделу рада чула, захваљујући којој је могуће непосредно визуелно опажати првобитне осете пипања".

Давно је, додуше, филозофски емпиризам, у складу с идејом Nihil est in intellectu quod non fuerit in sensu, развио идеју о зависности интелекта од чула. Класично доба је мислило процес сазнања према моделу виђења: ум ту функционише као светлост, као поглед бачен на већ постојећу стварност. Јасно је да тамо где, на пример, простор служи магијско-религиозним сврхама, по својој суштини већ емоционално утемељеним, то дејство мора испасти још интензивније разноверсније. Али није реч само о томе да је егзистенцијални простор неодвојив од духовног. Па ни о томе да градски простор већ по себи нуди огољени ритам нанизаних, простих чулних утисака. Почев од антике, уосталом, мислиоци и песници радо су замишљали градове као људско тело, с артеријама и венама кроз које теку реке пролазника и кола.

Реч је, напротив, о напетој исйовременосӣи збивања у унутрашњем монологу књижевних ликова, о сталном просијавању и укрштању мотива, стварних и архетипских представа, најзад, о основном утиску који читалац има - да їpag йрича сам сеঠe.

Небитна су онда физичка својства, није важна супстанца простора, већ сам доживљај, степен тактилности, блискости, сила привлачности што вреба 
у дубини погледа, што чини да се у њему јаве искре текстура простора која се, попут боје и ароме, у фрагментима раствара пред нашим очима и ствара посебно расположење, емоционалне потресе, откривајући њихов потенцијал као - аймосферу.

Знамо: о њој, тој естиейици аймосфере, све више расправља општа теорија чулне перцепције. ${ }^{7}$ И притом се упорно враћа на Бењаминов појам ауре. Њен настанак је отворен филозофски проблем, царство хипотезе. Колебања у њеном вредновању не могу се одвојити од онога што се обично назива „свест приповедача“. Сматрана испрва ужом, занемарљивом, временом се уздигла изнад „наше обичне свести“, као вреднија и шира. Као свест којој су доступна дубља сазнања и увиди. Пре свега тамо где се наслућује и „види“ као нешто још невиђено, што се још није дало чулима. То се посебно односи на описивање измењених, епифанијских стања, будући да су и она, после периода у коме су имала нижи статус, уздигнута на ранг „виших истина“.

Али сам доживљај атмосфере - тренутка када се „заборавља све остало“ и губи контрола над временом, када се изједначује с неком врстом опијености коју упоређују с мистичком праксом и психичким збивањем у сну, делиријуму или на прагу смрти, свеједно да ли се та измењена стања оцењују негативно или позитивно - неминовно изазива питање које нас овде највише занима: како се унутрашњи простори бића преливају у спољашње просторе постојања? Могућ је следећи одговор: до промењеног доживљаја света долази, прво, на подлози субјективно-чулног и естетски-метафизичког, потом на подлози сензибилног психологизма и снаге којом фантазија гради своје снове, и најзад, на подлози разигране имагинативне снаге симбола. Прелазна обе-

7 Истакнути представници су Гернот Беме (G. Böhme) и Херман Шмиц (Н. Schmitz). 
лежја су расплинута.

Утолико пре што у тим тренуцима нека чудесна спона на необјашњив начин спаја посматрача не само с околином него и са једним вишим светом, и што је нестварно, утопијска дејство атосфере све мање утопијско, док између облика материје и испољавања расположења постоје узајамни утицаји и дејства која обузимају сва чула. Јер, ако је „атмосфера“, метафорично

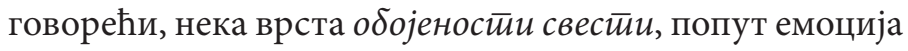
и расположења; ако је она заиста самостални облик сазнавања - у чему је онда њен утопијски карактер?

Одговор гласи: у томе што перцепција реалних или имагинарних ситуација обликује информације о могућим будућим расположењима. У томе што, будећи позитивну енергију, буди и оно латентно у нама, што помера границу људског тела, тачније: што активира скривену потенцијалну спремност тела за нову сарадњу организма и околног простора. Утопијска свест, као неки ђаво, куша, испробава начин на који се усамљени појединац сједињује и стапа са светом око себе, одбацујући и саму примисао да је свако јевађеље наде само варљива слика коју је пронашао неки непојамни демијург.

Мање је важно што такав спој и јесте и није могуће замислити. Што у такво флуидно и динамично обличје свако може уписати свој лични идеал. Далеко је важнија околност да тај спој остаје у сенци једног другог преображаја. Утопијска свест, наиме, постаје средство за бекство из заробљеног време-простора. За фиктивно бекство из овоземаљске „долине суза”. „Затворите ме у орахову љуску“, узвикује Хамлет, „и ја ћу опет мислити да сам краљ бесконачног простора“.

8 "I could be bounded in a nutshell, and count myself a king of infinite space!" (Hamlet, II, 2). 
За Шекспирове ликове, уосталом, једина прихватљива, и свака прихватљива утопија јесте утопија бескраја. Такав модел бекства, додуше, не изгледа као бекство у банални свет књижевне игре. Било би то вређање духа у име духа Утопије. Пре је то повлачење из тобоже реалног света, који непрекидно изобличава већ виђено, у скривену суштину светске мистерије. Њена слика остаје у том утопијском моделу сачувана и непроменљива. Већ млади Пруст, у својим исповедним „предосећањима” описаним у монументалном, класично засвођеном опусу, није хтео да замишљену Венецију замени стварном.

Наравно да све такве утопијске пројекције, гледано теоријски, нису више садржане у премошћавању дуалистичког односа субјекта и објекта у статичној садашњици. За њих је карактеристично не само да резимирају целу једну дисциплину мишљења у ритуалима, метафорама које обликује искуство моралне слободе. Јер, реч је уједно о стапању различитих семиотичких система, од којих један припада материјалној, други телесној, а трећи уметничкој стварности. Актуелна је управо њихова покретност, што чини основу за генерисање значења. Она се крију у начину посредовања. У наговештају. У пројекцији могуће интеракције између конкретних ситуација и потенцијалне будућности једног динамичног односа између тела и света.

А то је само наизглед једноставно. Не због пуке чињенице да се тако преносе и најсуптилнија обавештења потребна за веродостојност тренутка. Већ управо зато што се њихова уверљивост проверава на парадоксалан начин: увођењем у фиктивну конструкцију - утопију. У алимернатиивну верзију стиварностии. Или, сасвим уопштено: у алтернативни модел човековог постојања, његовог позиционирања у свету. Јер, док на површини утопијски говор често наликује стилским 
вежбама интелигенције и фантазије, импресионистичким сликама тренутка и атмосфере - из његове дубине извире безброј узнемирујућих питања. Из преклопљених слојева текста избија прави хук револта, безнађа и резигнације, изазване људском историјском судбином.

Управо би зато у ширем филозофско-утопијском разматрању, с обзиром на временитост и отвореност света, феномену атмосфере морао припасти ранг својеврсне conditio humana, будући да се атмосфером пред-свесно катализирају активности, које се, зависно од стања у малом и великом свету, тек реализују. Прво, зато што представља искључиву и врхунску евиденцију. Друго, најважније али најскривеније, зато што је приципом бивства као свеопштег узајамног огледања, све повезано са свиме.

И треће, зато што у дубини свих утопија лежи најстарији хрипћански мит - сан о злайном іраgy. Да је утопијска свест најомиљеније средство за бекство из заробљеног време-простора у неко „краљевство које није од овог света“, предсказивала су, наиме, већ рана хришћанска учења. У њима је наш текући појам будућности, времена уопште, подвргнут радикалној ревизији. Верници ће бити „уранополити“ (Павле у посланици Филипљанима), њихова је судбина „бекство на небо“, у Нови Јерусалим, у небески „златни град“, а дубоко провиденцијални смисао тога бекства садржан је у речима Павла: „Овде немамо постојана града, него тражимо онај који ће доћи“ (Јеврејима, 13:14). Уранополити су становници једног другог Града, оног небеског и вечног; Млечни пут је њихово трајно боравиште.

Према замисли непознатог аутора Писма Диоіене$\bar{u} y$, за које се сматра да потиче из другог столећа н. е., ${ }^{9}$ уранополити нису космополити. Нису ни грађани овог све-

9 Е. Жилсон, Филозофија у Среgюем веку, Нови Сад-Сремски Карловци 1997, стр.13 
та, још мање локал-патриоте. Они су васионски неимари, грађани неба. Тако су, доцније, себе називали хришћани у паганској римској империји када су њихову цркву прогониле римске патриоте.

Њихов положај се зацело може означити као бизаран и парадоксалан. Овде, на земљи, уранополити за-

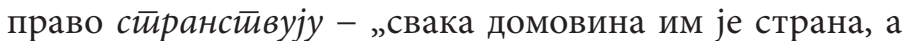
свака страна домовина је њихова домовина“. И загонетни покрет синаитског монаштва и исихазма имао је по свему судећи, у касновизантијско доба, у освит турских освајања, сличне одлике, иако се, захваљујући његовој издвојености у великим самодовољним заједницама, мало зна о начину живота и свим видовима испољавања хришћанског осећаја својственог овим монасима које историја цркве назива „синаити-исихасти”. Живећи у савршеном миру, у разним крајевима и земљама, већ према судбини која им је допала, уранополити, пак, надвисују све. Надилазе сродство по језику, крви, земљи порекла или државном грађанству - свим оним поделама као немилим последицама вавилонског проклетства. Обузети истим архетипом, они су, посматрајући ствари idealiter, у потпуности остварили једну unio socialis perfecta. Мала минијатура коју садржи Facundus-Beatus приказује анђела који помоћу трске „премерава” идеални тлоцрт Новог Јерусалима.

Идеја, пак, урбаних космополита имаће и дугу книжевну традицију. Давне 1648. године изашла је књига Семјуела Гота Nova Solymna с индикативним поднасловом Jerusalem regained, утопија идеалног града која се често приписује Милтону. Сан о граду је овде уметникова способност да као неимар свеобуватне цивилизације следи верски императив Доброг и Праведног. Али - био је претерано запео лук. Такву утопију су са различитих страна тумачили и као карактерну 
ману. Стога је и противудар био свеобухватан. Замисао усрећивања човека, разочарана у својим утопистичким очекивањима, изазвала је жестоке сатиричне реације. Идеји баптиста да у верским ратовима освојени немачки град Минстер такође назову Нови Јерусалим, али и градским утопијама и робинзонадама сваке врсте, супротстављане су, тако, веома оштре просветитељске сатире.

Најубојитија је она у Волтеровом Канgugy. У њој се деца играју с дијамантима. О томе се понешто може наћи у све обимнијој литератури о књижевној утопији. О старим и новим мисионарима. О изгубљеној и прижељкиваној безазлености душевног живота, а у исти мах разборитог прорачунатог спокојства. Али оно чега није било, или чега нема довољно, то је издвајање ове идеје и њених литерарних остварења о градским космопилитима као засебног, теоријски још неоткривеног предмета сталних а не спорадичних, уз то колико је год могуће међусобно повезаних и неком општијом замишљу руковођених истраживања.

Гдекад се проблеми градске утопије разлиставају као процес сазнања, обично у жељи да се радикализују неке утопијске књижевности које заговарају заокружену визију света: чудесни мит града, метафизику урбане стварности, епифанију њене судбине, одбрану невиности, слободу односа, животну авантуру и пророчанску машту као духовне вредности које се остварују искључиво кроз урбану културу. Референце нас овде воде од Имануела Канта који „никад није био тужан у свом Кенигсбергу", и није га напуштао ни по који цену, па до савремених тумачења Вулканескуа, Шпенглера и Бењамина - до њихове дубоке привржености култу града у коме бивство тежи да буде интегрално.

Наравно да ванвременски космополитизам уранополита добија другачији и обухватнији смисао када 


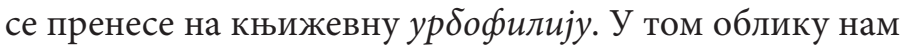
се градска утопија указује у двострукој призми. То су најпре знатна проширења и допуне у које би ушли како су то звали егзистенцијалисти - варијетети на-

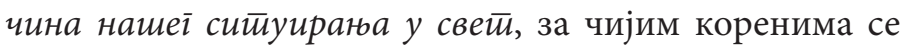
неуморно трагало у етимологији и граматици језика, у целокупној духовној традицији. А са њима и позиционирање самих аутора утопија, тих плаховитих бића која, следећи своју велику вокацију ослобађања и „бекства од урбаних зала" (Stadtluft macht frei), намерно бркају здраворазумске чињенице, те у погледу своје непоколебљивог утопистичког убеђења сведоче у складу с традицијом римских фидејиста: „Верујем, јер је апсурдно”, „Извесно је зато што је немогуће”. Од Тертулијана, за кога иронично кажу да није необично што је почео као адвокат, до филозофа Серена Кјеркегора, апсурд вере у немоїће представљао је оружје са којим ратник утопије креће у битку за побијање скепсе.

То је уједно разлог због којег се не може избећи паралелизам с неким битним аспектима религије, чији облици се спасавају у еститици чак и кад је аутори одбијају. Њен објекат је summum bonum и њен циљ је сйасенье. Пројекат урбане утопије, пак, нуди посебан коิд живљења, те је њен циљ посебан начин вредновања стварности, а да би се тачније могле видети његове форме, потребно је изнова проучити одговарајуће текстове, јер без њихове поетике, без проучавања ранијих наративних и жанровских облика којима су уоквирене идеје, теме и сижеи - без тога, разуме се, нема и не може бити разумевања ове књижевне подврсте као самосталне целине у ширем систему културе. Она ће, нема сумње, открити једну независну и самосталну форму утопије, свет за себе, свет са својом посебном физиком и метафизиком, са једним амбијентом у који се писац редовно враћа као повратник, никад као гост. 
Урбаној машти нису постављене границе па је „космополитима“, примера ради, Кристоф Мартин Виланд назвао и ликове Демокрита, Хипократа и Еврипида у свом историјском роману о античком граду Абдери

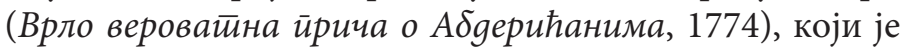
делом сатира, делом ретроспективна утопија. Опремио их је свим оним карактеристикама што спадају у ту категорију „светских људи”, узнемиривши својом горком иронијом европски грађански свет којег је бескомпромисно жигосао тврдим потезима свога пера.

Но, мање је важно да ли је ова унатраг окренута утопија - у којој град Абдера у Тракији свакојако опонаша Атину, и где заплет, с могућим алузијама на Бруна, чини препирка око магарчеве сенке, где се учи језик птица - више писана у духу киничког филозофа Менипа или је само једна езоповским језиком конструисана сатира на једно доба које стоји за нама преко два столећа. Још мање, какву улогу у свему томе има легендарни тип надменог интерпретатора-свезналице, Номофилакс. Битно је да се већ тада, пре радикалних последица изазваних рушењем система феудализма 1789. године, утопијска нада усмеравала на моделе ре$\bar{u}$ росиекийине уйойије, на изгубљене изворе у митологизованом грчком свету, на савршено јединство заједнице засновано на принципима аутентичног живљења.

У ову категорију спада и однос према општем устројству света, то јест, филозофија. Успоставио га је и Виланд на нарочит начин - у складу с утопистичком идејом о постојању једног тајанственог реда космойоли$\bar{u} a$, једног „невидљивог друштва које, под тим именом, вековима, више од свих других тајних друштава, врши важан и трајан уйицај на све што се одвија у свету“. ${ }^{10}$ Једну од бројних, саркастичних контрафактура так-

109 Das Geheimis des Kosmopoliten-Ordens, in: M. Wielands Sämmtliche Werke, Leipzig 1796, Bd. 30, S.113. 
вих тајних друштава описаће Пекићева футуристичка „готска прича” Луче Нової Јерусалима, која извештава о „савршеном” (комунистичком) друштву завејаном „у поларним мећавама дубоког Севера". ${ }^{11}$

И док су визије свете Хилдегарде из Бингена сугерисале слику о Небеском Јерусалиму, њеног земљака Виланда су - као озидани, фигурални узор и нераздвојни пандан овоземальском граду, или као што је то случај са реквијемом In paradisum у историји литургије - непрекидно пратиле и овоземаљске представе о граду Христовог гроба. Биле су то представе о стварном, географском циљу свих крстиашких йохоgа у Свету земљу, чију инспирацију је, зацело, у мањој мери изазвала наклоност према исповестима светаца. Још мање је то могла бити пљачка као искључиви мотив или подстицај који ће омогућити полет трговине у хрићанском свету. ${ }^{12}$

Баш као што се, треба и то рећи, верски занос и даље непрекидно мешао с нестварним светом витешке фикције. Има га у бројним наративним остварењима средњег века - не на последњем месту у Диреровом апокалиптичном графичком приказу Новог Јееусалима као средњовековог града. Спајала их је бесмртност која се обећава верским ратницима, бесмртност у верности војсковођи, и најзад, бесмртност у вери као у бројним пијетистичким визијама.

Али су зато опсада и спасавање овоземальских градова у стварности били у знаку парадокса - имали су наглашени предзнак негативне утопије. На олтар њихове славе полагани су животи. На то нас трајно

11 Нови Јерусалим. Јеgна іотиска йрича, Народна књига, Београд 2004, 158.

12 У то више не верује ниједан озбиљан историчар. Уп. нпр: Јасques Le Goff, Srednjovekovna civilizacija Зайаgне Evrope (prev. D. Stošić), Beograd 1973, 96. 
подсећа судбина оног ратника који је спасао од непријатеља у средњем веку италијански град-државицу Сијену. Ратник је чврсто веровао да спасава град Христовог гроба. Грађани су, опет, не знајући како да му се одуже, предложили да га убију како би га после могли славити као свеца!

Али се ни представе о Јерусалиму нису држале стварних, топографских датости. Довољно је поменути Лутерову слику Бога као јаког іраgа и тврђаве (Ein' feste Burg ist unser Gott) у његовој славној протестантској химни која се надовезала на 46. псалм: „Бог нам је уточиште”. Град овде, дабогме, симболизује бескрајно, мистично утонуће у божје биће, али његова рецепција у склопу саме химне није мање важна - уз несмањено дејство постала је заједничка својина бројних протестантских заједница. Али баш тамо где је реч о изванредном стваралачком снагом обликовном споју мистичног и појмовног, треба имати у виду да су такве предстве Град, често означаван као „пупак света“, апстраховале у виду - круга. Пример ове рецепције је и Барбаросин кружни свећњак у катедрали града Ахена. Тај круг је, међутим, пресечен крстом на четири једнака дела. Према тој идеалној слици, створеној у аналогији с визијом Небеског Јерусалима, конструисани су, уосталом, сви готски градови: „У сваком случају, цео средњи век се непогрешиво држао тог стила: град без 'четврти' био је незамислив, и тада је по свему судећи, морао настати израз 'градска четврт ““13

3.

Градске утопије су у овом веку поново постале предмет актуалних расправа - не без опасности од не-

13 W. Müller, Die heilige Stadt. Roma quadrata, himmlisches Jerusalem und die Mythe vom Weltnabel, Stuttgart 1961, 59. 
споразума. Од појаве „смрти“ приче, приповедача и његове улоге наовамо, њене метаформозе указују на неисцрпност и необично дејство овог наративног дискурса. Разлози су обично тражени у временским интервалима који стално преиспитују вредности, руше системе и изнова пишу правила пожељног живота. Понекад као бекство из света предодређеног и проклетог да буде овоземаљски. Некад, опет, као „ведру контрафактуру” која ће разјурити демоне негације, одложити дејство заразног „конструкта невере и скепсе” и свеопшти пад у песимизам. Језик је ту израз парадоксалне имагинације чија упутства за избављење спадају у библијски сценарио.

Укратко: историја књижевности постала је после деветнаестог века повест бурног расправљања с утопијом. Као што постоје стотине дефиниција и слика модерне утопије, тако је велик, готиво непрегледан, број разноврсних интертекстуалних и поетичких веза које она успоставља са ранијим остварењима утопијске литературе. Оне се мире само у песничкој имагинацији. Њен заједнички утопијски став је схватање идеала који надилази емпиријску стварност.

Чак је и песник Рилке, наизглед удаљен од свога времена, прижељкивао њену метафизичку утеху. Бежао је из великих градова у „градове у малом”: у замкове и дворце својих мецена, у „камена острва” руских манастира места која ће Фуко означити као „хетеротопије”. Клечао је пред иконама са својом сапутницом Лу Андреас-Саломе, очекујући да се у роману „отвори једна сасвим нова страна будућности, на коју се неће пренети целокупни збир кобне прошлости“. На завршетку Великог рата, који је као ураган прохујао Европом, песник „невидљивих анђела“ и езотеричних Сонейа йосвећених Орфеју био је тек један од многих који су веровали да без утопије нема праве енергије слободе, па ни месијанског спаса. Уверен је био 
да се изгубио - послужимо се Шлајермахеровим речима - онај јединствени „моменат бескрајног живота“"14.

А то значи: да нема ни наде, ни вере, ни душе, ни среће на земљи, јер снага полета што незадрживо тера у будућност, „која је окренула леђа“ романтичним іраgским уйойијама из времена Нове сииварностии и Баухауса - свим оним порушеним кристалним звездастим катедралама, култним местима посвећења у космичко-ирационално, у мистику йоисииовећивағьа с космосом - сада је, парадоксално, била утемељена на празнинама стварности.

Као да је сасвим заборављена њихова дуга традиција - од Филаретовог ренесансног „сна о граду” (Sforzinde, 1465), који попут Платонове идеалне архитектуре града конципира једнако идеалну муниципалну организацију, све до Жил Верновог „челичног града” France-Ville (1879); од Граgа вритова Е. Хауарда, Простираноі ірраgа Френк Лојд Рајта, Зракасӣог̄ ірраgа Ле Корбизјеа и Хабликових пројеката кристалних здања, па до заносног експресионистичког филма Фрица Ланга Мейройолис. Поетике су сада нудиле поражавајућа искуства. Уметнички продукти проказани су као пуки конструкти који неуверљиво фингирају као могуће оно што будној процени и трезвеном уму изгледа неоствариво. У њима више не тиња она неугашена романтичарска жудња за другим простором, потреба за хормоном среће и бекством у друга поднебља - есхатолошка потреба за утопијом хармоније и лепоте. Другим речима, они дају бледи уметнички израз ономе што у стварности тек виртуелно лежи.

Магистрална промена парадигме догодила се у тренутку када је моћна виталност утопије изгубила опкладу с ништавилом анти-утопије. Пред провалом њене „готичке маште” у XX веку, утопија све више

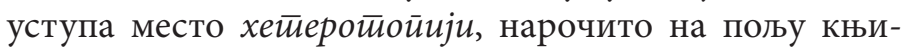

14 Fr. Schleiermacher, Über die Religion, Hamburg 1958, II odelj. 
жевности, филма и архитектуре. Истини на вољу, као нови наратив, као савремени феномен који у себи носи амбивалентност и форму једне „искривљене“ алтернативе - у том смислу што се манифестује као заклон и прибежиште - хетеротопија заправо не постоји као јединствена дискурзивна формација. Она је пре изврнута, театрализована, угурана међу градске кулисе. Видећемо да се јавља у двоструком виду: неочекивано, спонтано, стихијски, као ургентни програм новог прапочетка, као импровизовани план спасавања, али и као парадоксална потреба за заштитом, за мирним уточиштем у већ ишчезлом и давно прохујалом времену.

Па ипак, горка искуства историје нису до краја укинуле потребу за утопијама. Замишљене као средишта која инспиришу општи развој културе, чувене уметиничке комуне уочи Великог рата и током њега, као и бројне, по свему живописне енклаве-оазе, артистичке колоније, урбане заједнице и „пустињске комуне” у Калифорнији, представљале су својеврсни азил за социјалне аутсајдере - уточиште од растројеног и девастираног друштвеног система, покренувиши у првом плану филозофске медитације о човеку и његовој онтолошкој судбини: бивствовању у свету, односу према добру и злу, према стварности и слободи избора.

Тиме је утопијска митологија била спуштена на земљу и сместа опет фикционализована. Осим у оствареним сновима о новом свету где ће квекерски колони, кад се искрцају из бродова, раскрстити са грешном Европом и решити да граде строги али праведни свет по својој мери. Или пак у новим насељима званим New Harmony - у свим освојеним, „обећаним“ или поново задобијеним земљама о којима су писани романтични путописи - те заједнице су, наиме, листом избегле у фикцију, ушле у књижевност, иако су у стварности од- 
бациле град и приграбиле природни рефугијум, живот у колибама или под отвореним небом, који постаје опрека граду. „У градовима је лоше живети: ту има одвећ много олоша". Тако је говорио Заратустра.

Та је опрека била јасна, да јаснија не може бити: у радним, верским и уметничким колонијама се живи вегетативно и органски. У граду се живи механички. И док је у колонији човек природни продукт околине, у граду је околина вештачки продукт човека. Међутим, сви ови „природни облици" заједништва, као претеча еколошке свести - почев од оснивања легендарне „Језуитске државе” у Латинској Америци и пустињских верских заједница које следе хилијастичке идеје и утопије есхатолошке оријентације, преко анархистички надахнутих уметничких колонија и разних видова „кибуца” у којима влада дисциплина кошнице, па до стварања једног urbs in urbium или малих градских комуна: „градова у граду”, тако званих „егзодуса“ и „градова на ивици“ - сви они имају своје законе, ритуале и знакове који долазе са свих страна, али и заједнички циљ: да спасу човека осредњости, резигнације, стрпљења, историјског дремежа - да разоткрију званичну идеју гра-

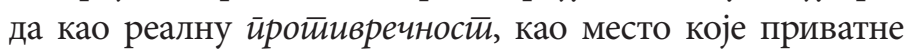
пороке претвара у јавне врлине, и да читалачкој публици поднесу, као у „бистром огледалу”, друштвене могућности његове природне и сасвим неоптерећене реализације, у којој политички и административни дух неће гоподарити као нека слепа сила.

Шта се још из те шароликости може закључити? Најпре то да идеали савршеног друштвеног развоја не чине праволинијску ниску утопија; да не представљају бројаницу која се наставља у недоглед. А затим, да њима влада комплексна логика супротности - борба између утопија и дистопија. Поготово што су у новом добу, у „времену екстрема“ (Hobsbawm) искрсла питања у 
специфично новим условима који захтевају ширу оптику. Маркантни, бурни преокрети историје, као што су ратови, показали су се веома инспиративним за носталгичну пројекцију идеала потпуне равноправности и слободе, за алтернативне друштвене пројекте који у двадесетом веку сједињују у себи негативне и позитивне црте, критику и наду.

Ту се најбоље види како утопија, у ствари, одговара једном специфичном домену разумевања реалног, па је њено истраживање дуго било сматрано за једно од привилегованих подручја супротних идеолошких полова политичке мисли. А са њом је - у терминима дијалек-

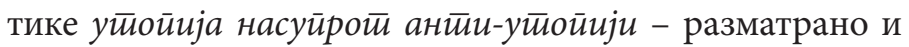
основно етичко питање: да ли је ново научно тумачење тријаде моgел-їраg-йойребе стављено пред исте проблеме с идејом напретка? Да ли му одговра паралална еволуција термина напретка? Да ли, уопште, неоходне друштвене илузије, у које се заклиње савремена урбана нарација, одолевају, сазнајнотеоретски, изазовима модерног тоталитаризма?

На почетку није био, како је Фројд говорио, злочин. Био је то, напротив, за целу утопију Модерне, сан $о$ злайном іраgу који помиње Елијаде: сан који се одиграо на почетку Времена, ab initio, као архетип, као пример и модел за било коју људску активност. За разлику од Маркса који је човека дефинисао као „скуп друштвених односа”, или од Фројда који у њему види скуп комплекса коме треба скинути маску тично несвесноі, за овог филозофа антропологије, човек је несумњиво скуй својих митиова које без знања носи у себи и са којима се управо несвесно, нехотице препушта свету у било каквим околностима, космичким или историјским. ${ }^{15}$

15 M. Eliade, Fragments d'un journal, I. Gallimard 1973, 315. 
За разлику, опет, од Борхеса који „најстарију причу о утврђеном граду” везује за утопијску „сеобу душа" у љубави између Јелене и Париса; за разлику, најзад, од целе Модерне, убеђене да ништа није случајно и лишено значења у васељени, Постмодерна је осуђивала класичне утопије, видећи у њима неку врсту предигре тоталитарних система. Као промотор ирне уйойије која доминира у веку закрвављеном од идеолошких система што се немилосрдно оспоравају, она презире ружича$c \bar{w} y$ утопију, али та grotesque en rose, како је подсмешљиво назива Сиоран у огледу Исйорија и уйойија, цвета и даље, наставља традицију нарације која размишља о човеку као бићу које може повратити смисао целине света у духу Хесеове Иірре сииаклених иеерли.

Најкасније с популарним Мерсијеовим времеполовом (L’an 2440, rêve s'il en fut jamais) из просветитељске 1771. године, долази до занимљивог помака од просторних утопија ка временским. Омиљени лик књижевних утопија, йуйник који осваја далеке просторе, постаје путник кроз време. Из епског сценарија потиснут је полиграф с документима о фантастичним земљама у пртљагу. Након бурне дискусије с пријатељем филозофом о неправдама у граду, безимени јунак Мерсијеовог „сна свих снова”, буди се у Паризу будућности. Преокрет је вишеструко занимљив, јер док је у старим утопијама идеални град већ био створен, сада је, поглавито у позитивним пројекцијама, некадашњи пасивни посматрач постао homo faber; он се укључује у изградњу идеалног града - заједно са другим ликовима који постају фактотуми једног ауйенйичним реалијама украшеног простора.

У градској утопији, наиме, будућност није празан простор из којег бије horror vacui, напротив. Она је одређена структуром наше перцепције коју стиче- 
мо током живота. Али док конзервативни ум полази од претпоствке да је утопија друштвено субверзивна, да за њу нема ничег што неће бити подвргнуто провери, анализи, довођењу у питање, она је за мање скептичне умове ту да обезбеди увећану аутномију, али и да поништи контролу доминантних друштвених ауторитета. Стога и захтева хитно успостављање примордијалних веза човека, препознавање урбане структуре као обрасца или елемента склопа свести, неодвојиво везаног за човеков утопијски напор да створи свет који ће имати смисао, свет о којем говори Луј-Себастијен Мерсије.

Епски градови, Деблинов Берлин и Белијев Петроград, Борхесов Буенос Аирес и урбане визије Гарсије Маркеса, упечатљиви су примери уметничких остварења, али су то и на други начин, на начин обликовања паралелних светова. Овде није реч о фиктивном простору и утопијском времену као код Хесеа или Гетеа, где се у у апстрактној „високој кули” сажима све што је човечанство створило на пољу сазнања, узвишених мисли и уметничких дела у „неким својим стваралачким временима", а што су потоњи периоди ученог посматрања свели на појмове и учинили интелектуалном својином. У њиховом имагинарном универзуму, наиме, постоји и један „вишак стварности” који се противи

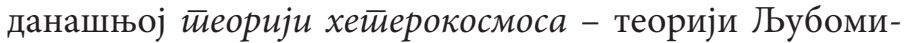
ра Долажела која оспорава значај стварног простора у фикцији.

За разлику од њега, Умберто Еко тврди управо супротно: да „морамо да призовемо све своје знање из геометрије, које смо стекли у стварном свету, да бисмо нестварни свет учинили могућим“ ${ }^{16}$ Реч је о надградњи

16 Umberto Eko, Šest šetnji kroz narativnu šumu, Beograd: Narodna knjiga-Alfa, Beograd 2003, 95. 
која организује простор и друштво. С правом је примећено да се у Џојсовом Уликсу читаочево знање геометрије примењује и на фиктивни романескни призор у коме ликови „опуштеним шетачким корацима” прелазе преко познатог „малог кружног трга пред црквом светог Ђорђа, и то дијагонално, пошто је свака тетива у кругу краћа од свог лука“. ${ }^{17}$

Нема, рекло би се, драстичнијег примера који би дочарао обим у коме је стварност нашла уточиште у естетској утопији - у царству „лепог привида”, царству које се дуго сматрало јединим боравиштем уметности. Оно се нуди једној посматрачкој свести која открива блискост човека и света у отвореном простору интенционалности између акције и појма, воље и ума, света и јунака, који својим телом доживљава тело естетског предмета, све док не постане оно са́мо. Сличности и аналогије - интерференције између новог и препознатог - падају у очи утолико пре што савремена решења градитељског карактера неодољиво наликују пластичним утопијским визијама.

Обликовање таквог града има три основна принципа. Најпре пада у очи - іеометиризација. Једноставне форме, попут круга или квадрата, остављају печат на тлоцрту града, као и октогонални и радијални систем улица, који одликује други принцип: ценитрализација. Оба принципа указују на трећи: на зативорености. Тиме је достигнута „ненарушива хармонија“. Узоран просторни облик симболично одсликава узорно друштво. Центар града постаје „геометријско средиште“ општег друштвеног бића, његовог „живота у хармонији“.

Сличности сежу и даље. Постмодерни, глобализовани град као суштинску арену модерне егзистенције

17 Džojs, Džejms. Uliks. 4. izdanje. Prev. Z. Paunović, Beograd 2008. 653. 
одликује - спектакуларна осредњост. Он је без историје, површан, анониман, вертикалан. Утемељен на руинама међуљудских односа и остацима виталних градских структура, на својеврсним празнинама егзистенције и „лукњама стварности“, човеков живот је презасићен нечим сасвим другим: фикцијом, виртуелним. Окружују га опсене, привид, симулакрум. Умрежени глобализовани свет у своју паучину ухватио је и заробио стварност. У таквом свету, отуђеном и неуротичном, утопија добија нову улогу и нову шансу. Али, у чему се она тражи и налази? У чему је, уопште, бит савремене градске утопије? Не указује ли се она на дијалектичан начин - истовремено као завршетак и као почетак: почетак утолико што што је аутор одлучио да од постигнутих позиција даље мисли, или тачније: да мисли унатраг?

Моја прва теза, наиме, гласи: књижевност не ишчекује нове појаве, барем не увек, него се заклиње у старе. Штавише, у односу на утопије прошлих времена, наше доба се указује као „крај” класичне утопије, бар када је реч о пројектима друштвеног преображаја. Насупрот томе, ретиросиекииивна уйойија се оказује као изгубљени рај, увек тражен, никада пронађен. Подразумевајући конструкцију већ на нивоу чулног опажања, она све више постаје приватна пустоловина у тражењу неке идеалне Постојбине, давне и будуће, радије давне, у заметеним траговима, неголи будуће, као заокруженог, универзалног конструкта живота. Углавном, неког окружења различитог од оног савременог, актуелног. Све потврђује да луцидност и утопија историје истовремено или, боље речено, да луцидност утопије представља оно што избија из романа̂ о граду који су писани аналитички и дигресивно, субјективно и храбро.

Стога моја друга теза и гласи: утопије XX века теже преображају йојеgинца. Довољно је да се књижев- 
ни, неретко аутобиографски лик сети неког детаља, неког упечатљивог микротопонима, неког дирљиво јасног тренутка - као код Дина Буцатија, чијег јунака

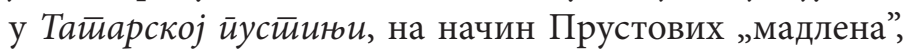
мириси у тврђави подсећају „на далеке године, лепоту неких недеља, веселе вечери, изгубљено дјетињство"18 - како би, у својству легитимног наследника великог духовног искуства, одједном пронашао смисао лудила постојања, како би се помирио са јучерашњим светом, откривши задивљујући низ архаичних слика које подсећају на магијско-религијске структуре, на симболе чије порекло није нестало из историје колективне свести: кулу, лавиринт, центар, границу и праг.

Притом је и праг ауторове свести пробијен већ у тренутку када има на својој страни старе фантазме, своје и туђе снове, митове, знакове које му окружење непрекидно шаље. То није инфантилна жеља за повратком у неки „музеј невиности”, то је носталгија за осећањем целовитости коју му је историја украла или је крије. За њу су способни само они pii diligentesque viri Хермана Хесеа, они смерни и савесни људи, за које се, додуше, не може доказати да „заиста постоје”, али који су уз напор њиховог писца заоденути тако високим степеном уверљивости да се управо по томе може сматрати да, према његовим речима, „у неку руку и постоје”.

Тај осећај целовитости могуће је потражити у новом йpeйopogy, у ренесанси свих садржаја и вредности културе какву симболизује Хесеова Иіра сйакленим иерлама. Магијско призивање највећих достигнућа ума и духа одвија се на њиховом највишем степенику - у музици. Разлог је прост, јер њихов дом, њихово средиште није у простору, него у gуши йојеgинца: у лепоти

18 Dino Bucati, Tatarska pustinja. Rijeka: Otokar Keršovani, 1972, 20. 
големог духовног здања које зрачи и када су нестали његови неимари. Универзум је, по Ничеовој сугестији, пре свега музички универзум. Ту, у његовој хармонији, обитава права стварност, она дубока, смислена стварност у којој се не „пролази само кроз просторе, већ у истој мери кроз времена", 19 у којој се, другим речима, непрестано померају њихове кулисе, препознатљиве попут музичких мотива и баш попут њих подложне безбројним изменама и варијацијама. Али правог појединца да је покрене, правог слуха да је чује, нема.

Нема га ни међу мандаринским интелектуалцима огрезлим у александринизму. Међу тим архиварима који су давно изгубили „дрскост проницљивости”. Понајмање међу мудрацима који скачу у понор - да створе себи илузију да испитују ништавило. Тек је великом „магистру игре”, дато да - свирајући на оріульма - овлада универзалним вредностима које, неподељене на строгу науку и поетску фантастику, побеђују време и навиру са свих страна попут слика што нечујно силазе са манастирских зидова. Оне су главни јунак Хесеове утопије која из будућности слави прошлост као божанска музичка кутија. Нека непојамна енергија, снага сећања, покреће хармонију сфера, раскрива све што је време прекрило заборавом.

Хесеов пројекат „утопијског насеља” Касииалије несумњиво је замишљен као цивилизацијски контрапункт. Као модел који пркоси варварсту Трећег рајха. Посвећен је васпитавању духовне елите: музичара, математичара, филолога, филозофа и историчара уметности који, у слутњи надолазећег ужаса, беже из корица својих књига у „стварни свет”. Утопија врви од „досељеника" из других књига, од ликова преузетих из светске

19 Х. Хесе, Изабрана gела, Београд 1979, V, стр. 244. 
књижевности и њихових аутора који не живе у „правом” времену. Идеја велике синтезе знања, „јединства свих духовних занимања човекових, идеја универзалности, нашла је свој савршени израз у нашој узвишеној игри". ${ }^{20}$ У једној игри, опет, која се јавља као нека врста васӣосйављене хармоније свих духовних вредности и садржаја. Utopia renovata.

Али, у настојању да своју утопију види као нову еволутивну етапу, Хесе не може да избегне парадокс. Тачније, два парадокса. C једне стране, сматрајући подједнако вредним све историјске облике и садржаје, а да притом сам не ствара нове него се само са старима „игра”, он заиста подсећа на архитекте позног деветнаестог века, који су знали да граде у свим стиловима, али нису имали властити стил. Хесе је и сам становник Утопије са несрећном свешћу коју је отуђила лектира историје. Стога, парадоксално, из још удаљеније будућности, пева о Касталији као о прошлости: „Нема више Касталијских школа. Стари се одмара / На рушевинама, са перлама у руци, / Хијероглифима, који су некад много значили, / А сад су само шарене ђинђуве од стакла”.

С друге стране, опет, пада у очи најважнија црта „повратне утопије”. Њен идеал је непрестано духовно усредсређивање, стална, непрекидна концентрација преко које се долази до стања сабраности, унутрашње тишине и коначног увида у суштину игре. Циљ игре наликује математском идеалу средњовековних херметичара. Она се протеже од симболике бројева до избора тонских редова. Она би тако да резимира све што је настало у великим духовним замасима, да из обиља сазнања извуче есенцију, из хаоса збивања хармонију, из збирке бројева збир, да сав духовни свет сведе на

20 Исто, VII, 215. 
музички концентрат, да му удахне свој дах - да би га још једном створио.

Убрзо након изласка Иїре сииакленим иеррлама Хесе је отписао 1. новембра 1943. швајцарском историчару Роберту Фаесију: „Јако ме обрадовало што сте структуру моје утопије тако тачно схватили и тако добро формулисали: она показује само једну могућност духовног живота: йлайонски сан, не вечно важећи идеал, већ један могући свет, али свет који је свестан своје релативности”. Тај утопизам окренут „класичним вредностима", тај пут у обрнутом смеру, та миграција у просторе где је све повезано у космичком ритму и сродству чудесних случајности, заснован је уједно на теорији и методи стапања различитих нивоа свести о целини бивства.

Како да назовемо ову веру у целовитост духа? Како да одредимо покушај стварања једног паралелног света, издвојеног у самодовољној заједници, истовремено окренутог прошлости и будућности? Да није сувише очигледан Хесеов ескапизам, његов покушај да класичне вредности претвори у утопијско средство избављења изазвано хаосом Другог светског рата, једино убедљиво објашњење би се сводило на филозофски став: ми напросто живимо у времену у којем се идентитет разграђује и експлодира у бујици коју је сам изазвао.

Али шире гледано, овде се још једном потврђује неопходност нове жанровске одреднице за текстове чија се фабула, додуше, одвија у $\delta g y \hbar н о с \bar{u} и$, али је у целости окренута вредностима $\bar{u} р о ш л о с \bar{u} u$. То је смисао ретроспективне утопије: да у исти мах буде архив иррошлоі $u$

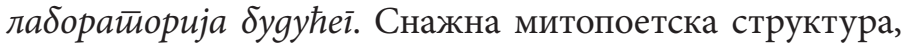
неочекивани духовни занос у „духовно оскудном времену", сведочи уједно о педагошком еросу који би читаоца, тог немог саговорника, требало да оплемени, просвет- 
ли, учини свеснијим у сваком смислу. Он ће онда бити у стању да, захваљујући фикцији романа, створи своју слику о игри стакленим перлама, онако како је то формулисано у чувеној причи Пуйовате на Истиок. „Јер наш циљ, дабоме, није само нека земља или нешто географско већ је то и домовина и младост душе, то је свугде и нигде, јединство свих времена".

Стога се лако намеће и дефиниција: реч је о микроуйойији. О месту којег нема, али које је, парадоксално, ипак ту, у облику другог, замисливог у будућности а пониклог на још старијим духовним матрицама. Ако, пак, имамо у виду речи главног лика који каже да у највеће вредности наука, обожаване лейоиее и меgийација, да је „култ истине уско повезан са култом лепоте, а сем тога са медитативном снагом душе”, онда то - заједно са Хесеовим „платонским сном” и Кантовим мислима да критика естетске моћи суђења мора да засводи сазнања и моралну теорију - већ претерано јасно упућује на немачку класику и њену теорију историје. Још ближе: на историчара Буркхарта, који се у овом „роману у кључу” појављује као Патер Јакобус. Буркхарт је још 1846. записао: „Пре но што нагрне опште варварство, желео бих да се још једном погостим на гозби образовања, како бих једном, након што се истутњи друштвени неред, могао бити активан приликом неизбежне рестаурације”.

Овде морамо застати. Не би се могло рећи да књижевност не посеже за још старијим матрицама. Пресудна је, наиме, појава да - чак и кроз трансформацију митских модела - долази до непосредне рефлексије мита на градску стварност. Више је него очигледна сугестија наратора да је то један нематеријални ентитет који еманира из материјалног тела. Утопизам je, по томе, метафизичка активност, јер он треба да буде 
суштинска критика Човека и Живота која писцу помаже да се вине у митске висине. Што је овај однос мање специфичан, уметност је моралнија. Из чега, додуше, следи закључак да је утопија најморалнија уметност.

Управо је Џојсов Уликс дао свој допринос овом поглављу из перспективе своје митске антропологије. Његова митска носталгија је утопијске природе. Подједнако плод учености, ерудиције и стваралачке маште, она - речито колико и изричито - доказује да митско није сасвим нестало из модерног наратива. Камуфлирано, маскирано наносима цивилизације, постало је само нейрейознайливо. Џојс, који често не верује ни у шта изузев у своју сумњу, схвата га озбиљно на незабораван начин: ако не унесемо емоције у наше почетке, не преостаје нам ништа друго него да поново освојимо сенке наше митске прошлости и поверујемо да је покретачка снага планете душа.

Као кад песник Сумароков, у једној од ода, пореди императора Русије са Нептуном који влада воденим стихијама из којих се уздиже Петербург; као кад Мендељштам у Риму види далеку утопију; као кад Бродски пише свом „римском другу” Овидију или кад митологизира маглом и димом заоденути Петербург у коме све вољене особе остају с ону страну реке Неве-Стикса - тако и Џојсов Уликс обнавља утопијску картографију сећања.

У њој су нашле своје отеловљење све контрадикције пребујне утопијске имагинације. У њој једнодневна историја урања у мит, а јунак у град. Половина његове подељене личности припада прошлости, у којој глас, мисли и звук делују упечатљивије од фотографије, будући да се, упркос виртуелности, повезују с коментаром наратора.

Врач и хирург, говорио је Валтер Бењамин, односе се међусобно као фотограф и стваралац који продире дубоко у ткиво приказане реалности. Његова на- 
рација производи много богатији и трајнији утисак од снимка којег одликује „дискретна суздржаност”. Јер, то је „слика кратке памети” и опустошених сећања, само заустављени тренутак живота, мала смрт. Треба се присетити првих реакција поводом gаїеротиийије и првих отисака сребром на стаклу које помиње песник Макс Даутендај. Људи су се бојали да погледају те прве слике, веровали су да особе, које су биле на слици, и саме могу да их виде.

Град Даблин је, међутим, духовни омотач у коме Џојсови описи, акрибични и маштовити у исти мах, постижу разговетност друге врсте. Она отвара својеврсни парадокс, будући да је у истом тексту могуће спојити пројектовање градске свакодневице и „реалног живота” јунака дела на неки идеални живот - на митски, утопијски живот који добија превагу из једне епизоде у другу. Из тесне коже наративних правила воде, такође, многи путеви. Ту је најважнија идеја повратка, у смислу у којем психоанализа говори о „повратку потиснутог”, а што подразумева утисак накнадног дејства.

Око хомеровског јунака окупљају се остале теме. Модерна Одисеја нема зацртани циљ са препрекама које ће на крају бити савладане. То су препреке друге врсте: телефонски разговори, гласине, предања, док у игру улазе силе које по сваку цену морају да преузму контролу над наративом. Утопија се згушњава, постаје шагринска кожа која се све више скупља. Шаре на њој остављају траг застрашујуће уметности контрапункта, вишегласја и монтаже, у којој видимо очигледан одјек естетике у којој влада искуство и поетика града.

Стога лавиринту града одговара компликовани, лавиринтски језик. Инструментариј граматике показао је њему своју недораслост. Зачетак наратива којим доминирају фрагментаристи, моралисти, ствараоци језика, представља провокацију у односу на приповедање 
које нема адресу, које не зна чему стреми, куда иде. Свака секвенца се храни асоцијацијама што навиру изнутра или споља. Случајни покрет буди асоцијацију и повлачи следећи покрет, а обична реч ствара посебну емоцију у процесу читања којим доминира Херклитова мисао - очекујемо неочекивано. Надреалистичко манипулисање пропорцијама, како телесним тако и просторним, одриче реалност стварном свету, будећи сећања: нека су блиска, друга имају хиљаду и више година. Будућност је увек у прошлости.

Како се оне у сваком појединачном случају остварују, то је већ нека друга прича. Слична и различита од толиких других нарација, градска утопија је непролазна у својој пролазности, а та посебност код великих епских дела постаје судбином. Господари паралелних светова уводе нове конфликте у моделе ретиросиекк-

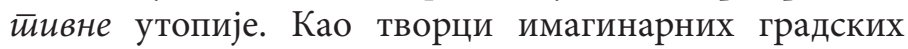
универзума они заправо, уводе и више од тога - један оживљени дух града, настојећи да спиритуализују „јучерашњи свет" као референцијални модел. У време брзог живљења, али још бржег заборављања, они се труде да изнова дефинишу човека, у односу не само на оно што је видљиво, већ и на оно што је заборавио.

Као да почива на некој грешци у перспективи, васкрс егзистенцијалистичког доживљаја градског духа има и другу намену. Треба да послужи као узор. У необичној хронологији кружења идеја у двадесетом веку, у веку у којем преврати иду у низу док наративни модели преокрећу битне утопијске елементе, могуће су неочекиване промене парадигме. У њима се најзначајнијим управо чини присуство поменутог ретроспективног елемента. Прорицање повратка у душу прошлости са којим се, неретко, призива и митско посвећење завичајног тла, испуњено је чак императивом, али не категоричким, не таквим који заповеда, него с надом 


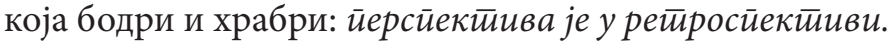

Она сугерише да стварност постоји само у естетском привиду, као лековита представа целовитости. Отуда и допадљивост коју доноси, јер живимо у свету у коме напредовање рационалности, знања уопште, не иде глатко и без озбиљних отпора, те све више показује знаке забринутог замора. Живимо у свету у коме је мит истинитији од реалности и где је наличје илузије једна друга илузија. Могуће је, такође, да писци понегде следе утопијску матрицу а да тога нису свесни. Као што чувени господин Журден пише у прози не знајући то.

Њихов дубљи смисао се, зацело, не објављује у тренутку, у првом читању. Послератна књижевност са сликама бивших, сад већ непостојећих простора развија, наиме, једну сасвим нову форму која следи утопијску мисао и њену „енергију наде“ - или је, барем, изнова ставља на дискусију. Та нова форма има вишеструку функцију. Мало би било рећи да она у двоструком смислу припада свету фикције. Најпре показујући да као ретроспективна пројеккција једним делом изражава општу истину о врлинама идеалних грађана и непорецивој изврсности њиховог полиса ослобођеног силе и неправде, а онда откривајући да је све што су људи раније имали био само сан - само један сан, али се његова снага састоји у томе што компензују изгубљене

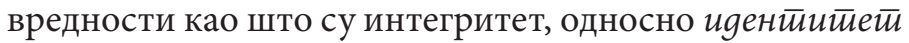
човека, чулно јединство с природом, миром, сигурношћу. Свако тумачење градске утопије у овом кључу мора да започне од овог начела противречности. Веома смо далеко од једноставног решења.

Завеса, још једна завеса, спушта се пред погледом управљеним у будућност. Као нада окренута прошлости, утопија ове врсте лишена је уобичајеног пророчанског набоја, оног ужареног профетског тона којим заводе редукционистички умови у оквирима практичног нара- 
воученија. Она још мање одговара апстрактном програму сачињеном у строгом „геометријском“ духу урбаног пројекта; овде, напротив, сабирање сећања на оно што је одредило личну судбину постаје симбол и део шире судбине друштва. Шилер је сличним обртом дефинисао песничку уметност као трајну антиципацију будућег. „Оно што смо осетили као лепо, једном ће нам изаћи у сусрет као истина", нада се Шилер у песми Уметиници.

Да би спасили аутентичан садржај своје мисли, писци вишеструким, чак супротним подстицајима покрећу урбане слике своје тичне утопије. Она силогизме замењују ентимемима и праве разлоге чини само могућим или вероватним, али се она притом не ослања на социјалне конструкте већ на динамичну психологију личности у роману - на улогу загонетног, самотног интелектуалца зачараног у урбаном крајолику, на његов однос према историјском свету. Његов портрет, отуда, уопште не личи на идеалан, класични портрет појединца издвојеног у свет општих идеја.

Он следи захтеве конкретног духовног искуства, само што то враћање, што тај повратак прошлости, нема задатак откривања предачких корена. Прошлост је, напротив, активни симбол аутентичног искуства, унутрашњи, психички садржај човека без којег је свако сазнање несавршено. То је симбол опстанка једне особене formae mentis која пориче прихваћене вредности у спољном свету пролазности и агресивног материјализма. А то, макар посредно, објашњава зашто йоврайне уйойије остварују највиши степен „ванвременске савремености”.

Иако је тачно уочено да је физички простор све ужи - град, зграда, стан, соба, на крају простор који обухвата тело појединца - овај симбол ствара простор већи од свих димензија на које се навикло индивидуално искуство. Штавише, нису ретки писци који нијансирају ове претензије, налазећи да субјективност приказивања 
може бити објективност њихове субјективности. Мисао коју треба узети у обзир. Као и запажање да је од општих синтеза у утопистичкој медитацији занимљивија лична синтеза сваког човека понаособ.

То је друго кључно обележје нове утопије: померање њеног фокуса са друштва на појединца. Могло би се у први мах помислити да је стога потребно преместити и фокус истраживања с узрока на последице. Очигледно је да све изразитији постаје раздор између јунака и доба у коме живи; логички: јер јунак, откривајући његове противречности, показује његову неодрживост и оправданост захтева за променом, и психолошки: јер се читалац отуђује од противречног света и приклања јунаку и његовом животном програму.

Један другачији поглед на ствари могао би нас упутити на сигурнију оријентацију. Јер, „принцип наде” не показује више наивност Држићевог негроманта који у прологу Дунgа Мароја сања утопијску Индију. Пројектован у прошлост, он управо представља покушај помирења супротности. Покушај да се чиста апстракција идеја и осећање жеље, дати у безвременом, бесмртном сјају поетске симболике, помире са свешћу о пролазној, и погубно колебљивој, несигурној стварности.

Наравно да такве утопије нису ни критика опптег стања ни опозиција општем и нарушеном друштвено-културном амбијенту, већ напросто њихов помирљиви репрезентант. И док њихов статични карактер гаси у корену сваки динамизам, цела прича о прошлости пре личи на огромну илузију што бесциљно мучи и одузима сваку иницијативу, на сетну апологију градског декора и ритуала, на слатко-горки сан о лепоти која је отишла у неповрат. Утопијска слика прошлости се зато приближава путем извесности једног безвременог језика у граду ко зна ком. Као ретроспективна утопија, она наликује бифокалном псеудомеморијском поремећају. 
То је онда пука драматургија меланхолије у утопијском градском роману. И то је оно што чини град у исти мах иреалним и надстварним, као у делима Виланда, Маркеса или Фокнера. Град се, парадоксално речено, не налази у граду већ на позорници. Највећи део бившег живота, у чији се повратак све мање верује, налази се испод позорнице, у његовој подсвести, у дубинама сећања. Сећање је сазнајни процес. Реконструкција прошлости подразумева зато не само његов повремени епифанијски блесак. Треба признати да су то много дубље и суптилније анализе од оних што се јављају у тренуцима озарења. У њима се огледа везаност за систем вредности који би могао поново бити на снази у новом времену или новој средини. Теоретски, тиме се у савременој књижевности отвара дискусија о новој gуховностии.

Али, како треба разумети онај парадокс који се разокрива као колосални throwback, као својеврсни повратак у будућност који, неочекиваним обртањем, глаголу $\delta и \bar{u} и$ даје неумољиву извесност - ga је неш-

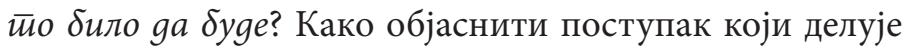
као повратни, окрепљујући оксиморон? Како, на крају, дати и саму жанровску одредницу за појединачно дело које изгледа као ендемски примерак непостојеће врсте, као примерак каквог је увек било, али као да и није?

Најпре тако што није реч о повратку утопије, него о утопији повратка. А затим тако што се утопија сада протеже на укупност историјских и духовних претпоставки које од писца чини, по речима Ремона Арона, „пророка након догађаја“. Односно, како је то, много раније и много прегнатније, дефинисао романтични пес-

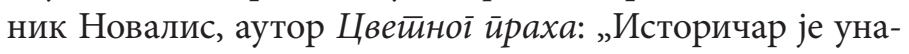
зад окренути пророк“. То није мала прича о истини која се насумице јавља духу. То је постојана суштина нове, ретроспективне, градске утопије. Које је то време, када почиње, каквим је идејним и друштвеноисторијским 
животом испуњено, докле је трајало, који су његови резултати и чиме се завршило, то су питања од прворазредног значаја за будуће истраживаче овог жанра.

Новалис је, на пример, у потуности био свестан претеране идеализације средњег века, коју је сматрао нужном у времену општег „рашчаравања” живота и света, у времену гашења ауре једног света којим би поново морала завладати машта. Градићи су, тада, били „острвца у времену”. Са њиховим нестанком је нестало и колективно сећање: приче и бајке, причане столећима, у „временима када је за то било времена”. За њиховом звездом, путем којим се иде у супротном смеру, у прошлост, кренули су многи. Зафрански је у својој књизи о Новалису подсетио на речи којима ће млади Лукач, један век касније, започети своју чувену Теорију романа: „Блажена су времена за која је звездано небо земљописна карта проходних путева којима треба ићи”.

Визија „могућег света“ остварује се, дакле, као покушај реконструкције изгубљеног. Али ту није увек реч о сигурним концептима, о вечним идејама које важе у свим ситуацијама; нема ту говора о судовима који су дати једном за свагда. Уза сву оправданост мотива и племенитост намера, њен методолошки принцип има различите мотиве и отвара - веома различите перспективе. Знамо да, за разлику од Брехта и социјално ангажованих писаца који сликају „честар градова“ као место хаоса и проклетства, велики град постаје идол футуриста и утопијских активиста. Он утиче и на сам начин уметничког и књижевног представљања правца којим становници града треба да крену како би се досегло „опште добро“. Те градске утопије су, међутим, одвајкада имале друго име. Звале су се визије.

Остале су да се преносе речи експресионисте Лудвига Рубинера из предговора за антологију Зајеgница.

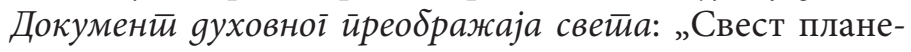


те о потреби људске заједнице је неуништива у даљем хиљадугодишњем светском процесу, на чијем почетку се сада налазимо “. ${ }^{21}$ У овом предговору који је постао славан, Рубинер не дефинише модел срећног света, савршеног урбаног друштва у незаустављивој моралној прогресији. Напротив. Он би само да се отисне од оне сиве декорације једне истовремено реалне и надреалне животне пантомиме непосредног живота, који више не зна шта би са собом.

Tо је утопија у настајању. Utopia in statu nascendi. То није утопија остварена у прошлости, а није ни она чији се програм одвија у некој далекој будућности. То је, напротив, прави конйракулӣурни тренд у свом зачетку - дискурс који се, агресивно, оштро и узбудљиво, поиграва деформацијом, иронијом и гротеском, али који у исти мах, пратећи развој злоћудних преображаја, испуњава свакодневицу визијама бескрајних могућности које град пружа. Град, жив, узаврео, у непрекидном је процесу промене. Стога исписивање његове судбине руши хоризонт традиционалне урбане утопије, настојећи да покаже како сваки град увек има два лица. Како и најбеднија појава може скривати лепоту истине што ће се једном, некад, објавити свима, будући да непрестано репродукује васколики „театар света“ којим доминира нужност промена. Али разорну снагу те визије њени заговорници не приписују институцијама, него аутономној мудрости појединца, његовој савести, а не прописаним нормама и колективним вредностима. Тиме се руководе романописци XX века.

А тиме се може објаснити и делотворност, продуктивност мотива утопије: да би се зауставио процес пропадања идеје о срећном граду, није довољно да му се

21 Види о томе: L. Rubiner, Die Gemeinschaft. Dokumente der geistigen Weltwende, 1917. 
супротстави изворна позитивност „племените“ прошлости. Није довољно да се некадашњи викиншки Даблин појави као саставни део свих доцнијих романескних Даблина, па тако и овог савременог. Потребан је наговештај могућности да се тај процес повратка позитивно преобрази, и то полазећи од оних чинилаца који су већ били на делу. Филозофски речено, царство нужности и пролазности мора бити замењено царством слободе и постојаности, независно од историјског интервала.

Једноставније речено, утопија о којој се овде говори поразумева меланхолично осветљење и оног што је постојало, што је већ добило своје животно обличје, и оног што се само наслућује и што тек очекује своје поновно, накнадно остварење. Оног што обухвата домен меморије и што се проширује као визионарска слика промишљених сазнања, што је предмет емпиријског искуства и што је садржај утопијске свести. Тако схваћена утопија, коначно, укључује још једну двострукост у основном, егзистенцијалном смислу - она, видели смо, означава физичке границе човековог животног простора, али и узвисивање у област метафизичког зрачења његове људске драме.

Сам град, дакако, поприма карактер острва, издвојеног, поринутог попут брода Mayflower у непознате воде, управљеног ка непознатом америчком континенту чији видици обећавају, подстичу и анимирају, инспиришу реконструкцију менталних структура, далеко од Европе, тог „континента развалина”. И књижевна тема Петербурга, која се пред нама отвара на страницам руског Сребрног века, заправо је обрада мотива острва - мотива града-цитаделе у одосу на остатак Русије. Борис Гројс завшава свој оглед Имена іраgова закључком да је Петербург „смештен на нултој тачки у 
којој се губи све оно што се збива на другим местима". ${ }^{22}$

Није зацело нимало необично што се та слика савршено уклапа у Фукоову слику брода као идеалне $x е$ $\bar{u} е р о \bar{u} о \overline{u j e . ~ С т в а р н и ~ т о п о л о ш к и ~ п о л о ж а ј ~ г р а д а ~ п о д у-~}$ пире такву идеју усамљеног, пловећег острва. Издвојена, измештена позиција одговара инсоларном коцепту, па су и коментари данашњих социолога префињенији и језгровитији када суштински смисао налазе у тези да издвојени положај фаворизује могућност свестранијег, објективног просуђивања самог процеса реализације.

Појам „острва стреће“ јавља се код светог Анселма, који тврди да је прелазак са замишљеног на реално постојање сасвим могуће. ${ }^{23}$ Сада је, међутим, и модерни град утопијско острво - нова Атлантида: у граду се остварује концепт новог живљења. Када Аристотел у Поетиии каже „Задатак песника није да говори о томе шта је било, већ о ономе што ће бити“, онда су његове импликације тако широке, да је сама чињеница да се она одбацује или прихвата готово довољна да одреди жанровску скупину којој припада утопија. Видећемо да су то велика врата кроз која пролази интенција наратора у коме се зачиње могућност нове рефлексије: прилика да се изнова проблематизују норме живота у циљу продуктивне противречности.

Духом, формом и идејама утопије прожети су градски романи с краја деветнаестог века, дела неонатурализма на почетку века, као и романи експресионизма у време Великог рата. Отуда је њихово терминолошко одређење погодно за означавање једне макроструктуре унутар целе културне епохе. Њену суштину је Хобсбаум описао као непревазиђено „клуп-

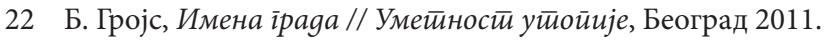

23 Е. Жилсон, Филозофија у среgюем веку, Сремски Крловци-Нови Сад 1997, 208. 
ко неспојивих екстрема". Управо се због тога, међутим, оној далекосежној методолошкој претпоставци већине истраживача који говоре о готово механичком, цикличном враћању градских утопија, о сталним понављањима стереотипних „места“ или формула, могу придодати извесне критичке примедбе методолошке природе. „Повратак“ градских утопија зависи, наиме, од тако много различитих узрока, мотива и констелација, при чему су сви они, поновимо то још једном, увек присутни као преплет, интеракција, интерференција. Али су то увек попришта са неким ванвременским утопијским садржајем и значењем.

Тој врсти безвремености, па и трајне актуалности топоса града можемо се приближити и преко реторичког жанра. Не само на класичан, уобичајен начин, преко наизменичног односа изворног и изведеног, или кроз расправу о различитим категоријама урбаног дискурса, већ и на основу анализе тзв. епидеиктичких и „безвремених жанрова“, као што су надгробни говори ('̇лıт́́

Ове су ейийафије - како их назива реторика вишеструко занимљиве. Оне, наиме, славе више иgеју месии $a$, аутохтони дух града, тзв. genius loci, него погинулог хероја и његов подвиг. ${ }^{24}$ Чујемо то и код Квинта Енија, главног „законодавца римског песништва“, чији епитафи здружују грчку и староримску традицију тзв. elogia. У Енијевом историјском спеву Анали, писаном у грчком хексаметру, стоји да „Рим још и сад од древних јунака, од прошлости живи“ (Moribus antiquis res stat Romana virisque $)^{25}$.

Притом су ови хероји само гласници што проносе славу и величанственост града. Само херолди што

24 В. Милисављевић, Каgа су љьgи ницали из земље, Београд 2016, стр. 158.

25 Прев. Р. Шалабалић. 
стално додају друге облике слави града која се никада на њима не зауставља. У томе се несумњиво може наћи део истине. И њу не следе само хеленизовани песници који су римску историју дали на латинском језику у виду епа in illo tempore. Утопијски „дух града“ заиста има ритуални и институционални карактер, иако нема сумње да у њему принуде жанра такође постоје. Њен нови лик је и готика, градска уметност сакралних објеката, катедрала пониклих из тела града.

Градска утопија и за романописце минулог века лежи највећма у митологизованој прошлости. Прошлост није празно време. У њој не одзвања само завештање носталгије за прохујалим. Све изгубљене вредности у чије име се људска, постојећа стварност негира, све неостварене норме које градски роман евоцира, зову се, у ствари, мир, сатурираност, спокој. Задовољство постојећим. Оно што означава наслов књиге Валтера Бањамина Haga y ирохујалом („Hoffnung im Vergangenen“). У традиционалном поимању утопије, садашњост се брише у име будућности које још нема, а можда је никад неће ни бити. Сетно сећање је, међутим, такође еминентно утопијска творевина која буди парадоксалну наду у минулом, прохујалом. Истина, врло опрезно, и са потврђеним инстинктима независности у односу на књижевне каноне.

Овај необични вид повратне метемемйсихозе, сеобе душе у већ проживљено прошло време, има и једну додатну утопијско-фикционалну црту. Наратор по правилу тежи да заусииави време и тиме одложи доцнији слом својих идеалистичких фантазама. Опремљена искуством неуспелих утопија, његова носталгија је угрожена сталним страховањима да се у судару с трауматичним реалности оне не распрше. Другим речима, и неко данашње не-местио би могло постати испуњена утопија само под једним условом - ако се трака прошлости одмотава унатраг. 
Трака прошлости? Понекад се утопијска носталгија протеже и по више векова уназад, као код великог барокног песника Мартина Опица и његове фантазмогорије о једном заборављеном српском граду смештеном на самом рубу Светог римског царства немачке нације (Златищиа), па и дубље у прошлост, до епохе дворског песништва у чијој машти се налазе острва попут Тапробана (Цејлона) на коме се година састоји од два лета и две зиме.

Или до архајских времена, до античких градова и Перикловиог доба. Посезаће се и за другим моделима ретроспективне утопије - између осталог и оним естетским. У првом реду, ипак, за римском цивилизацијом. За оним што романисти обично називају mirabilia urbis Romae. Ту изнова постаје очигледно како се, ношен максимом шито gаљь $\bar{\varkappa} о$ увертьивие, утопијски идеал најлакше остварује у просторно-временски одмакнутом. У премештеном или далеком, самом себи измакнутом и неистоветном.

Један од највећих песника латинског средњовековља, Хилдеберт из Лавардена (1055-1133), славио је управо оно што носталгија за величином „неупоредивог“ Рима нуди утопијском идеалу као „енергетско начело“. Уйойија руине, по њему, носи у себи далеко већи потенцијал истинитости од сваке истине саздане по целовитом моделу актуелне градске слике. Чак и када је њена позната дефиниција означава као pars pro toto. Рушевни Рим, штавише, надмашује, превазилази повластицу самог поређења: Par tibi Roma nihil, cum sis prope tota ruina; / Quam magni fueris integra, fracta doces. / Longa tuos fastus aetas destruxit, et arces / Caesaris et superum templa palude facent. ${ }^{26}$

26 N. E. Lemaire, Poetaes latini minores, Paris 1826, p. 206 . Up. i: Dieudonné, Hildebert de Lavardine, évèque du Mans, archiévèque de Tours. Sa vie, ses lettres, Paris 1898. 
Ако би, дакле, утопијска слика носила у себи неку истину, ако би, уопште, представљала себе као канонски утемељени ау $\bar{u} о р и \bar{u} е \bar{u}$, онда би то могла бити само истина контраста, истина разлике или неистоветности између садашњости и прошлости - диференцијални раскол као сан о непролазној лепоти којом је Хилдеберт, напросто, фасциниран. Ближи му је крст од паганског орла, али се ипак најрадије отискује у прошлост, далеко од властитог реалноі, историјског места. Будући да није кадар да христијанизује антику, он, можда и несвесно, паганизује хришћанство.

Веома учени надбискуп из Тура био је, уосталом, први хришћански песник који је, два века пре Петрарке, опевао непролазни сјај града испуњеног паганским симболима: Non tamen annorum series, non flamma nec ensis ad plenum potuit hoc abolere decus. „Ни низ година, ни ватра ни мач нису имале снагу да униште овај узвишени сјај.“

Оно што психолози подразумевају под носталгијом, а други означавају као „жал за младост“, доводи до поетизације и симболизације, до проширивања појма стварности, што је све повезано са раслојавањем језика у коме је утиснута моћ истовременог исповедања и прорицања, моћ призивања прошлости, њене прохујале величине и њеног континуираног обнављања у смислу једне идеалне морфологије живота. У њој је нада савладала носталгију, а утопијска ведрина потиснула жал за пропуштеним приликама и неоствареним жељама.

Описујући, меланхолично, збивања из прошлости, аутори бивају свесни, и све свеснији, и с тим очајнији, да су постали жртве неке светскоисторијске преваре, те им још једино преостаје да дирну ту непокретну сферу митског света илузорне свести, како би сам текст заиста постао збивање: стварање једне нове свести у читаоцу - недовршене, али коју покреће баш та 
недовршеност, та задобијена guстиани, тај неисцрпни рад утопијске критике на себи самој, рад који спречава да се упадне у пуки психологизам, у бесконачно огледало самопрепознавања. Њихови текстови сугеришу да је град загонетка. Зато се његова природа - природа града - мора истраживати, али највише због тога да би се у њој открила злослутна знамења катастрофа̂ које су се већ дочепале ауторовог живота.

Феномен урбане утопије описан је у романима насталим између два светска рата на сасвим нов начин, а самим тим је на нов начин изражен и феномен критичког модерног реализма. Реч је уједно о нарастању једне апстрактније, поетичније артикулације стварности, ослоњене на урбану субкултуру. Сада су меморијски кодови, истовремено лични и колективни, они који представљају упоришну тачку градских утопија. Није отуда необично што се и њихова суштина саопштава на начин који све виртуозније варира све видове индиректног говора, па отуда и хипотетичког, само моїућеї тумачења.

Личи на парадокс утопистичког типа, ако, имајући у виду „меморијску адресу” нарације, покушамо да укажемо и на процес који читавом захвату даје специфичну динамику. Након вртложног понирања у свет састављен од потиснутих успомена, сам текст постаје својеврсна зиданица. „Гра̂дећи свој град” саздан од суптилних меморијских делића, текст открива двоструку перспективу: наратор или његов лик живе истовремено у два света, и притом доживљавају унуйрашњи процес своје свести као ванску реалност.

И док за неке писце „прошлост представља земљу из које смо заувек прогнани”, у коју нема повратка, те је јалов и сваки покушај да се обнови оно што се већ мимо наше воље одвило и довршило, фосилизирало, претворило у беживотни артефакт - за друге 
је то управо повратак у будућност, описан као тегобна рестаурација „музеја невиности”. Он је наративно потенцирање епа. Резултат је ванвременско дејство споја фиктивне и референцијалне нарације као надградња онога што еп може учинити својим нечувеним преплитањем временскопросторних планова.

На који начин је онда прошлост, упркос протоку времена - или баш захваљујући њему - утопијска категорија? Одговор може звучати колико радикално толико и парадоксално: полажући право на успомене и снове о будућности као делу стварности, писци уводе поменути историографски моменат guстианце, који се међутим не примењује доследно. Тако у исти мах настаје амалі $а$ м: савремени роман или роман свог времена који је истовремено - утопијски роман окренут идеализованој прошлости. Одговор који се нуди јесте да такав роман није случајна фуснота књижевне историје, већ једна од темељних йоджанровских оgреgница утопије.

Стога узроке настанка не треба тражити далеко од саме дефиниције утопије. Додуше, у оном што се естетски појављује у категорији утопије више се не може уживати, а promisse du bonheur, то обећање среће, како се утопија некада дефинисала, не може се више наћи тамо где је лажној срећи скинута маска. Другим речима, ту је најбитнија чињеница да су - упркос упозорењу да понављање познатих ствари и улепшавање прошлости успављује свест уместо да је активира - есхатолошке оријентације и замах фаустовског преображаја света уступили место покушају да се реализује ретроспективна утопија повратка као савремена утопија која израста из прошлости. Да се, по речима Стефана Моравског, у пепелу потраже дијаманти.

То је први аспект. Други аспект отеловљују писци „свесног утопизма“, писци који креирају своја сећања као 
снове о будућности и онда очекују да живот прихвати њихове фантазије. То је покушај да се ирреко йрошлосиии

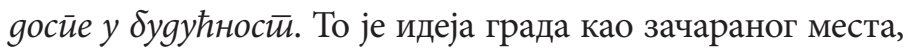
треће димензије, мегапростора на мапи сећања. Наиме, избегавајући екстензивност на коју подстиче не само велики број градских утопија него и велики број интертекстуалних веза са романескним сликама светских мегалополиса, у којима метафора градског живота изражава осећање отућености, могуће је указати и на неке мање познате пројекције утопијског као „суштински нестварног“.

Значајна упоришта пружају, притом, и она романескна остварења која с опсенарском лакоћом прелазе из реалистичког у нестварно-утопијски дискурс, тако да гдекад, примера ради, како Питер Акројд у свом (пре) обимном делу Лонgон: крайка биоірафија каже, постаје сасвим неизвесно, нејасно, да ли је то „велико тело града производ његових становника или су становници производ и пројекција њиховог града“. 27 И овде задржава своје важење општа констатација: и утопија и анти-утопија могу бити лични или колективни сан, али су по својим могућим последицама свакако стварне, свеједно да ли се манифестују у чулном или надчулном облику.

Визија града се понегде јавља као израз прерушеног начина да се буде у свету, који се у старинском костиму враћа уназад само да би за себе изградио властиту традицију. Да би понекад различите архаизме и фразе којима су говорили претходници повезао и претворио у својеврсну потрагу за новом-старом традицијом. Његова мисија је ураво трагање о којем говори наслов познатог Блоховог дела.

Али са̂мо трагање, призивање момената који се откривају као животни путокази, није овде никакво

27 P. Ackroyd, London: The Concise Biography, 2000, 177. 
„трагање за изгубљеним временом“, већ истраживање његовог могућег смисла. Чак и онда када се не завршава поново нађеним, испуњеним временом. Добар пример „свесног утопизма“ заговарају, на пример, Роберт Музил, аутор Човека без својстиава и његов истомишљеник Улрих, главни лик романа чија радња се одвија у Бечу, књижевној престоници Музилове прозе. Он не подразумева неки конкретан утопистички нацрт. Његова је утопија естетска. Не постоји план који би се под одрећеним околоностима, на неком другом месту или у неком другом времену, могао реализовати. „Оно што ја дајем у роману“, каже недвосмислено Музил у својим позним записима, „остаће заувек утопија; то није ни-

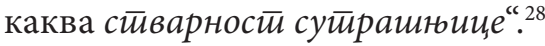

Принуђен самом стварношћу, дакако већ транспонованом на подручје фикције, на проверавање свих могућности за постизање неког смисленог циља због којег би вредело живети, главни лик покушава да конкретизује свој програм за корениту промену свог живота у граду, његових вредности и односа у њему, те је његов нацрт утопијске, „друге стварности“ одмах преобраћен у лични експеримент. Њена „могућа истина” je, каже се у првој књизи романа, можда изарз „још не пробуђених намера Господњих”. Она „није ништа мање вредна у односу на само постојање; напротив, она у себи носи нешто божанствено, некакав огањ, неки полет, стваралачку вољу и свесни утопизам, који не зазире од стварности, али је схвата као задатак и као изум”.

Довољно блиска да привуче пажњу, довољно људска да је човек осети својом, а стално подједнако далека, будући неухватљива, да би била вечити циљ испред

28 Robert Musil, Tagebücher, Aphorismen, Essays und Reden, Hamburg 1955,378 . 
човека, та фатаморгана људског идеалитета могла би, по Музилу, да буде трајан оријентир човеку на путу ка сталном напретку људскости у њему. Можда се у фрагментарности, у незавршености овог Музиловог романа крије најдубљи симбол. Јер, он говори у име свих романескних творевина које своје основно етичко стање изједначавају с основним утопијским доживљајем. Њега, при томе, занима само она основа утопијског доживљаја која би била кадра да издржи експериментални пут и готово опипљиву, емпиријску проверу.

Одавде није далек пут до закључка: утопија ни издалека није доктрина сањалачке пасивности пред даровима метафизичке милости која кује илузије у привидно широком распону - од несигурне наде до варљивог обећања. То је, напротив, доктрина живота, па чак и троструког живота: активног, афективног и контемплативног, преко којег човек на крају успева да урони у фикцију оствареног живљења. Писац је уживо заљубљен у „негда постојеће нешто”, у знаке и симболе конкретног, премда скоро заборављеног „каменог крајолика" и симбола градње, стремећи не према апстракцији или ка научном установљењу реалности, него према основним принципима егзистенције, према коначним и последњим суштинама - у непрекидном настојању да се, путем детаљне конкретизације, превазиђу границе између прошлог и садашњег.

Гете је, говорећи о Винкелману (1805), указивао на елегичну узопију таквог савршенства: „Само из даљине, само одвојено од свега приземног, само као прохујало” мора да нам се покаже сва прошлост. Утопијска слика прошлости се зато обично приближава путем извесности једног безвременог језика у граду ко зна ком. Овде се поново мора застати како бисмо схватили да распон таквог прегнућа има најмање две адресе: једна је упућена 
појединцу, личној судбини, а друга аутентичном свету који тек треба саздати или обновити.

Стремећи таквој „конкретној утопији“, патријарх утопијске мисли Ернст Блох је, слично Лефевру, посматрао свет као незавршив процес чије објективно-реалне могућности ваља конкретније, животније сагледати; он повезује људску праксу са Још-не-свесним, што га води „принципу наде“. Конкретна утопија је за њега сам процес реализације, у коме се оgређења буgућностии експериментално проверавају у непрекидном страху од губитка људског садржаја, губитка живота, у страху од изолације без аскезе. Могло би се, међутим, додати да је једнако утопистичка и сама жеља да се човек, који је у друштвеном погледу дисоциран, поново сабере, обједини уз помоћ уметничке свести.

Чињеница је, међутим, да се такви концепти могу посматрати и на контрастној фолији - у равни Фукоовог диспозитива, који тумачи друштвене односе моћи, облике знања и простора. Његова размишљања о хетеротопијама као „локализованим утопијама“ пружају занимљиву мисаону фигуру и отварају многоврсне модалитете осветљавања поља напетости између утопије и урбанитета. Али нам се још важнијим чини једно додатно, начелно разликовање утопије и анти-утопије.

4.

Анти-утопија се односи према утопији као анти-театар према театру. Људска нада се показаје као казна. С обзиром на критику живота каква им је својствена, разлике су крупне, мада, формално гледајући, обе имају извесне заједничке црте. Уйойија је констирукӣивна, gистиойија је gестирукииивна. Што једна канонизује, друга деканонизује, уводећи у своје програме демонију не- 
гативности, страсни скептицизам, претерану сумњу, спремност за велике поразе. Песимизам стоји у основи њеног морала. Још горе: чак и Ничеов оптимистички нихилизам изгледа безазлено у поређењу с неумољивом, леденом стварношћу „најгорег од свих светова”. Нигде се, заправо, коิдови постојања тако не разликују као у прогностичким варијантама утопије и анти-утопије. За прву је нужна илузија нешто као просценијум слободе, за другу је предворје трагедије.

Но две инверзне, обратне утопије се заправо надопуњују. Као визија и њена ревизија. Жестина анти-утопије је мера виталности утопије. Није им заједничка одлика само мит младих и апотеоза моралних вредности у епохама кризе. Повезује их то што су обе производ свести која се не мири с постојећим. Најзад и то што се одликују једнаком слободом у његовој осуди, иако се свака на свој начин разликује и отискује од постојећег света, чак и кад представља скуп неопрезних или смишљених огрешења о логику времена или простора - када се тоне кроз временске зоне или успиње у ледене, бореалне пределе неке невидљиве Хипербореје и урања у алпска језера Хесеове апстрактне Касталије. И када представљају остварење најсмелијих снова, и када су постављене наглавце - као хуманистички и друштвени слом.

Због тога оне нису мање мудре. Ни више гротескне. Но и без илузија о буржоаском свету и његовој дремљивој духовној пустоши из које желе да побегну, у случају опкладе у будућност, ствари постају одређеније. Многи би се радије определили за ружичасте снове - упркос честим и аутентичним изазовима мистицизма. Као некакви неверници-верници, incroyantscroyants, многи би, наиме, радије ставили улог на визију изманипулисане среће него на осећај зебње пред неким 
„ревизором” будућег света. Пред неким свеприсутним Великим братом.

Као „дан” и „ноћ”: у духу грчких филозофа, из те симболичне перспективе читамо будућност у двострукој призми. У њеној дијалектици фасцинира не само провокација црно-белих визија у односу на мишљење, него и трајност њихове заснованости на некој врсти апсолутне одбојности. Јер, док утопија заправо представља одбојност, парадоксалну одбојност према og $\delta$ ojно-йосйојећем, док стреми, спонтано-емоционално, ка измаштаном не-йосйојећем - анти-утопија, опет, представља отклон у супротном правцу. Као хладни перфекционизам који узима данак тела, душе и ума, најрадије извргава руглу утопију као принцип посредовања између среће и морала.

Марш утопије кроз историју личи јој на уже које се затеже до пароксизма. На опасност самозаваравања која се повећава сваким даном. На старе слике надовезују се нове: све су то нијансе сиве које распаљују различите фантазије, нијансе које дају додатну невеселу боју жанровским одредницама анти-утопије. Пресудно је, међутим, у свему томе то да, као ocyga утопије, и то као осуда нечег не-постојећег, искушавајући најдаљу границу онога што је било и оног што ће бити, анти-утопија све више постаје пророчки род приповедне прозе.

Давно пре Фукојаме, она, у суштини, означава крај историје. Откривена у првом таласу упереном против епохе разума, протеривана у подземље у раздобљима мира и напретка, поново би изронила када би човечанству запретила два анђела, Бењаминов „анђео уништења“ и „анђео историје“ са слике Паула Клеа: у време светског и хладног рата, у рулету живота и смрти, отуђења од природе, пропалих револуција и идеолошких самообмана. 
Антропологија анти-утопије заснива се на идеји јунака као пониженог и обезличеног лика људскости. Њена позитивна супротност, утопија, очигледно располаже већом слободом у сликању и процени људских могућности; са своје стране, међутим, подређује се једнако строгим критеријумима анализе друштвених веза. Право говорећи, истинска утопија не би могла да учини ни један корак „пре него што се поклони моралу”, на чему је инсистирао Кант; и мада је по себи грандиозна замисао, њено повезивање с моралом није нимало грандиозно, јер морал заправо пресеца чвор који утопија није у стању да разреши чим се супротставе једно другом. Сукоб утопије и анти-утопије представља неку врсту до (само)свести доведеног лукавства ума, којим се сваки опонент у овој бесконачној расправи о судбини света неосетно уграђује у тотализујући погон за успостављање Новог света.

Попут духа и природе, ума и бивства - оне чине две бесконачне стране идеја. Песништво их је одвајкада сучељавало као ватру и лед, као отров и лек. Новалис, који је сковао синтагму о историчару као „унатраг окренутом пророку”, сањао је о повратку у „лепа, сјајна времена" хришћанског средњег века. Сањао је његове слике, свечаности, метафоре, свете дужности и ритуале оріански добро уређеног вањског света и побожност добро поспремљеног унутрашњег живота. Цео романтизам стоји у знаку магичног идеализма, молитве која призива повратак у медијевални свет минстрела и минезенгера, у трубадурску утопију љубави као неиспуњивог сна, у замкове и дворце као „градове у малом”.

Он, тај светии сан из Новалисових Химни ноћи, може да се наслути у злайном мору іраgова. Са њихових високих кула пружао се поглед у плаву даљину, у

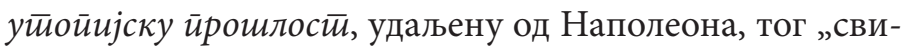


репог драматурга у театру европских судбина". Удаљену и од револуционарних збивања, од прозе свакодневног живота, чему је управо Хегел додао утопијску ноту: револуција сме да постоји само у царству наших представа, а „онда ни стварност неће одолети”. Средствима магичног идеализма, налази Новалис, обновиће се све. Не само градови, него и људи. Тада ће сваки човек бити свој лекар, можда ће, каже, бити у стању да „рестаурира" и делове свога тела.

Романтичари су тиме идеализовали само половину средњовековног света, ону ноћну и смртну и отели јој њену ужасну страну. Само што та контрастна слика, тај сан о кретању уназад има и своје додатно објашњење: романтичари, посебно они немачки, окрећу своје утопије у прошлост и да би се супротставили духу нове техничке анти-утопије. Дакле не зарад неке интеграције техничког (Robboterdichtung) и социјалног живота каква лебди пред очима савременика - већ управо супротно: у сврху превазилажења негативно вреднованог тоталног технизирања и духовног ништавила, какво налазимо код романтика свих времена и узраста. Наравно да однос појмова у овој бизарној једначини „утопија \pm анти-утопија” захвата при томе и подручје политичких датости. Како то треба разумети?

Левица и десница, раздвојене су, политички гледано, у својим програмима увелико, иако их од памтивека уједињује сама идеја промене, незадовољство постојећим. Понекад и трагично осећање живота. Подударање извесних појавних облика не може сакрити чињеницу да би утопија и анти-утопија, ове две, у нашем данашњем разумевању једнако уважене, варијанте „нестварног а ипак могућег” - када би тако рећи само за тренутак сииресле са сеঠе лииеерарну оgeћу - свака на свом различитом ступњу друштвеног осмишљавања 
преузеле и различиту политичку функцију. Хришћанске и хегелијанско-марксистичке вуліайе темељиле су висеће вртове своје утопије на драмској тензији ишчекивања бољег живота. Као што је за Маркса у Јеврејском $\bar{u} и \bar{u} а ғ у$ политика била „профани облик религије”, тако су и његови следбеници са зачуђујућом лакоћом преточили схоластичке тезе у секуларне и профане моделе.

Маркс и Енгелс су на крају 19. века видели у утопији сувишни реликт „преднаучног доба”. Читамо ли је из ракурса тзв. gujаматиа, из све удаљенијег претпрошлог века, намеће нам се њихова алегоријска слика о - пловидби. Прогласивши писца утопије за наивног светског кормилара коме су подвалили лажну бусолу, одбацили су и саму утопију као ненаучну јерес - као пуки резияуум из давних времена којег треба занемарити зарад тачних прогоза и конкретних партијских програма. Неколико деценија касније руски бољшевици су, додуше, пренебрегли ова упутства. Пре свих, активиста Александар Н. Богданов са својом утопијом Црвена звезgа из 1907. године.

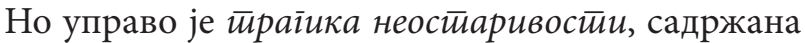
у покушајима да се политичка утопија реализује кроз диктатуру пролетаријата, изазвала троструки ударац, разоран и свеобихватан. Обновила је, прво, сумњу у идеју напретка, друго, у беспоговорно позитивни карактер технике, треће, у илузију незадрживог раста човекове свести о одговорности. Штавише, додатно је инспирисала анти-утопије. Јер, техника даје и узима. Изменила је лице града, осветлила ноћ, убрзала живот једних и скратила живот других. Изменила је начине производње, унела нове поделе, уздрмала поретке, државне и друштвене. Осећања отуђености и одбачености позвала су у помоћ фантазију.

И, као што то показују колорисане разгледнице с краја 19. века са летећим бродовима и кућама са 
точковима - одговори су били могући само изван актуелне моћи поимања. За Фојербаха и Фројда, то су пројекције неостварених жеља, прекорачење границе. За неомарксисте оне представљају трансценденције, надмашивања постојећих односа која указују на још неостварене могућности људске егзистенције. Социопсихолошки гледано, то су симболичне радње, којима се превазилази конкретна негативност спознаје света. Заборављајући да је стварност текста само језичка стварност, да је њен свет свет од папира, разни „секретари јавности”, „теолози ослобођења у области култуpe", повлашћени и неовлашћени критичари и аутори националних програма, тронуто су понављали и још увек понављају у крајње извештаченом и непотребно бучном вишегласју, како утопија не досеже ниво научне истине. Тако је и постало могуће оно што је, на први поглед, парадоксално: схизофрена симултаност наде и порицања, утопије и анти-утопије. Та експлозивна спрега разобручене, еуфоричне слободе и репресивне хомогенизације, трајно осветљава сјај и беду „видилаца кроз капије будућих времена."

Уколико је све то извесно, а јесте, где је онда стварно, аутентично место утопије на книжевним майама света, ако не на самој тесиивици бивстива? То је oঠeћarbe утопије без којег утопија не би била оно што јесте. И оно је одговорно за немогуће. Без обзира на место и време. Већ у Морово доба, када је и настао термин „утопија“, стварна егзистенција удаљеног места среће није била мање ирелевантна од њене локације. Када се данас поближе погледају Блохови појмови „антиципације“, „потенцијалности“ и „још-не-свесног“ - као уосталом и целе естетике која разјашњава како се уопште неки феномен пред нама помаља, искрсава, излази на видело - постаје јасно да географска димензија у ур- 
баном дискурсу добија само метиафоричну улогу, док временска задржава најшире могуће значење. ${ }^{29}$

То поигравање временском плановима у модерној градској утопији једна је од њених основних карактеристика. У тако проширеном значењу утопијског, фантастична реалност постаје онда део књижевно-естетског васпитања, од којег се очекује решење друштвених проблема, али и духовна обнова читаве културе. Овај двоструки радијус рефлексије, огледање фикционалности дискурса у дискурзивности рефлексије, објашњава целокупну критичку моћ „царства фикционалности”. ${ }^{30}$

Давно је примећено да су Блох и Борхес творци фантастичних реалности које се међусобно додирују и допуњују. Блиска зачудној литератури Борхесовој, Блохова утопијска инспирација повезује слободу и нужност. Управо као код Шилера: утопија је место сусрета идеала и нужности. Тако јединство неспутане маште и нужност моралног детерминизма нуде спасоносно стање насупрот стварности као патњи. Утопијско стање дарује само песништво својом уверљивошћу.

„Уверљивост” је, с разлогом, реч која дефинише судбину утопије. Тако је, ако вам се тиако чини, говорио је Луиђи Пирандело, заборављени мудрац са југа Италије. Али да би стекла меру убедљивости за многе, да би избегла „проклетство разочарења”, јасно је да, јурећи фантоме среће који треба да покрену историју, утопија мора унапред уклонити све узроке могућег агресивног обесхрабрења скривеног у антиномији између рационалности и непредвидљивости живота. Отуда и везивање за

29 „Das Noch-Nicht-Bewußte insgesamt ist die psychische Repräsentierung des Noch-Nicht-Gewordenen“. Ernst Bloch, Das Prinzip Hoffnung. In fünf Teilen, Zweiter Teil. Frankfurt a. M.: Suhrkamp $1985,143$.

30 Види о томе: Otmar Ette, Literatur in Bewegung, 2001, 258. 
прошле моделе није само вид апстрактног испољавања незадовољства, него и бунт против актуелне уметничке ситуације. У њој се пресложен систем значења књижевног текста редукује по мери политичке прагме.

Као оптимистичка антропологија, која од слободе покушава да направи колевку, романескна утопија прошлог века имала је све изразитији градски печат, за разлику од стварних оквира модерне Европе која се није стварала око градова, већ око држава. Но иако се свуда наметао други принцип организовања простора, време урбаних острваца, озиданих пунктова, малих ћелија друштва није пролазило. Зов комуналне утопије, оснивања града на некој „другој обали” која доноси авантуру, изобиље или вечни спас, и даље је покретао је машту и осећајност људи који нису успевали да нађу смисао колективне и индивидуалне судбине. Тај зов би и данас хтео да поврати наду у оно аутентично људско што се потискује и губи у планетарном походу науке и технике, а што би могло да постане конститутивни елемент једне алтернативе, то јест нерепресивне цивилизације.

Нада је за Ернста Блоха носећи принцип људске историје. Њоме дотичемо најдубљи слој утопије. Штавише, насупрот психоаналитичким теоријама, овај филозоф наде је развио нови поредак нагонских осећања: разликујући „већ испуњене“ и „тек очекиване“ афекте, и тврдећи да је аутентични афекат чежње увек - нада. А нада је за Блоха норма: када је она јака, свака анти-утопија постаје, у суштини, мали, безначајни приручник разочарења. Ту се онда, по логици ствари, поставља последње прелиминарно питање: који су то разлози због којих савремена урбана утопија - романи који лепшу будућност виде у прошлости - спектакуларно колико и неочекивано, улазе у духовну актуелност XX века? Jер таква инверзија је могућа само у бајци. 
Када је реч о блискости бајки с утопијама, у први мах нам изгледа као да је бајка на једној, а утопија на другој страни. Бар када се има у виду однос наивног и рационалног конструкта: разлика измећу позлаћеног іраgа-gвориа и модерне урбане аркаguје. Али, као што у бајкама оно ,Беше једном...' не упућује на прошлост, него на будућност, на могући бољи свет - у коме се, према познатој Литијевој дефиницији, збивања одвијају онако како би тиребало gа се оgвијају - тако се и за утопију, коју су називали „сном за будне“, може рећи да полази од представе о савршеном друштву. За Блохово опредељење за утопију везује се и једно друго убеђење. Његовом остварењу се аутор Духа уйойије и Принцийа наgе највише приближио захтевајући једну „нову молитву”. ${ }^{11}$

Упркос ломности ове реторичке форме, осетљиве на фразе, догме и пароле, утописта Блох, заговорник „конкретне утопије”, моралиста против своје воље, видео је, зачудо, у свему исти повод за „нову молитву”. За једну молитиву чији шапат ће одјекнути у главима многих, а то значи: за чежњу да се човек ослободи присиле чињеничног стања. Утопија је молитва, анти-утопија је пресуда.

Но ту је управо он, Блох, најближи призивању бајковитог, нереалног стања, јер таква утопија је испрва нешто невидљиво, што се такође назире тек после, кад је човек непоправљиво носталгичан. Он се најбоље осећа у малом, зачараном кругу, у делу града докле допире његов поглед, сетни, сентиментални, у коме људи имају огромне онтолошке хипотезе и мале, топле станове, огромну количину доброте и мале димњаке с родама, који надвисују звонике над којима се и по небу, шагаловски, возе сваке недеље сватови.

31 Уп. E. Bloch/F. Vilmar, Über Ernst Bloch, Frankfurt am Main, 1968, 96. 
„Све што је поетско мора бити налик на бајку”, каже песник Новалис у једном од својих фрагмената. У складу са тим основним доживљајем, романтизам на управо утопијски начиун спаја све области сазнања, песништва, филозофије, неспутаног маштања и сна. Ни утопијски град, ни сама држава нису механизам него организам; то је поетична спона што повезује тела, душе и духове. Предање француских бајки рококоа сливало се са мистичним учењем сйаса. Хофман је, тако, разликовао обичне, приземне људе од оних других, поетичних, створених за утопију, способних да осете чудесно у животу, па самим тим и праву повезаност ствари. Орган сазнавања постаје онда бесконачна свест: моћна филозофија идентитета, коју је Новалис назвао „магичним идеализмом”, хтела је да стопи живот и песничку логику, науку и религију. Отуд Шлегелова крилатица: „Романтична поезија је прогресивна универзална поезија" која утопијски замишљени свет „треба да учини живим и друштвеним, а живот и друштво поетичним".

Песник Новалис је био тај који је хтео да смисао трансеценденталног идеализма оствари у прозном фрагменту о Хајнриху Офрердингену, романтичној луталици и несуђеном трубадуру који утопију чежње за симболом „плавог цвета” не тражи у присности завичајног града, већ најпре у некој врсти „универзалног самоостварења", а то значи у духу Фихтеове филозофије субјективитета, на начин како је то формулисао његов савременик, филозоф Шлајермахер: „Сваки човек треба да на свој особени начин представља човечанство у некој својој личној мешавини његових елемената".

Али оно што је у овом пројекту самоостварења пресудно, то је повратак у време пре „великог отуђења” које су донели просветитељи, у „златно доба” средњег 


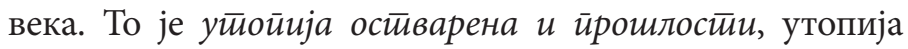
минулог као реакција на просветитељство, на пројекат „трезвености ума” - отуђења које собом носи рационалност. Неко је погасио светла у чистим разумом обасјаном здању просветитетљства, тврдили су немачки романтичари. Иза тога се крио разлаз између теорије просветитељства, сна о уређењу заснованом на уму и њеног практичног остварења: реалности терора, то јест, екстремних могућности рактичног рационализма.

Кристални градови епохе рационалности, снови о њиховом уређењу заснованом на уму, крили су реалну могућност терора над појединцем. Песницима су изледали хладно и празно, политичарима сувише принципијелно, а метафизичарима плитко и без маште. Као код поменутог песника латинског средњовековља, Хилдеберта из Лавардена и његове носталгије за „величином рушевног Рима", та уййија руине је имала већи потенцијал истинитости од апстрактног модела града. Она је за романтичаре била апотеоза субјекта и слободе. Божанствено, клицали су они, није ли то чаробно што се велика чуда живота не могу схватити рационално. ${ }^{32}$

Шта из овога произлази? И у бајкама се једнако остварују измаштани животни пројекти, који приказују свет какав би требало да буде. И бајке и утопије, уосталом, користе фантастику као елемент напетости у односу на стварност. Ништа мање типичан није ни стереотипни дуализам добра и зла, она манихејска слика света у којој бинарне опозиције „ружичастог” и „црног” суверено владају судбинама јединке и колектива. Спаја их, међутим, у још већој мери, једна необична околност. То је теорија која има плодотворну улогу у

32 Уп. С. Грубачић, Истиорија немачке кулӣуре, Сремски Карловци-Нови Сад, 2009, 2. изд., 318. 
психологији стварања и естетици рецепције - теорија по којој оба облика маште нису само инспиративна него и креативна.

Са њима, уосталом почиње читава серија духовних раздвајања која су у књижевном дискурсу нарочито упадљива, па тако и она између „витеза крста” и „витеза тужног лика”. Између онога који се жртвовао за човека и онога који се жртвовао за илузију. Као секуларизовани делови архаичних митова, архетипова и њиховог устрајног циркулисања у историји идеја, ови - условно говорећи - „облици маште” одвајкада креирају моделе у простору духовног стваралаштва, уносећи непрекидно преображаје у сферу уметности као такве. Само се њихови модели непрекидно понављају и умножавају.

Управо је Блох био тај који је говорио о бајци као о „најстаријој утопијској причи, у којој је одлагање значи будућност, а удаљеност циљ путовања. “[9] Сви ови елементи доиста су уоквирени, постављени и доступни у кохерентном, демонстративном дискурсу. Ту и тамо са понеком пророчком реченицом. Но, мада слична Вуковој дефиницији бајке, у којој се приповедају, до засићења, „чудеса што не могу бити“, утопија је свесна раскида између овог и оног света. Стога у њој и нема широке космичке солидарности свих ствари. Нема ни лагодне навике да се необјашњиво објашњава необјашњивим. Фантастика, у њеном случају, није никаква наивност која нуди „непрекидно одлагање”, инфантилно иступање из историје или упадљиво одсуство воље за духовним чином. Она управо говори о чину и начину бивствовања, а то је ултимативна метафизичка вредност, пројекција обликовања људске судбине.

Основна разлика бајке у односу на урбану утопију не крије се у просторној ограничености. Она не 
описује ликове који желе да се избаве из невоља у потрази за срећом у неком непроменљивом сталешком друштву којим владају краљеви и јунаци, патуљци и виле. Она критикује свет метафоричним језиком, приказујући слику идеалног или буквалног „врлог“ новог света, у којој виртуелност надвладава тренутност. Везивање за прошлост, међутим, до којег је нашем разматрању посебно стало, видљиво је у духовном братству са поетиком метафизичког и надреалног.

Иста техника је на делу и када је реч о анти-бајкама - књижевним остварењима која дају мистичну ауру бићима која су уроњена у свакодневни живот и наизглед баналне ствари. Такав је, на првом месту, Кафкин свет којег настањују животиње што говоре, коњи, инсекти, птице и бића којима би било место у правој бајци да није посреди једна другачија намера. Да ли је реч о утопији, о фикцији давања гласа неизрецивом, да ли се ради о рањеним субјектима и невидљивим бићима, да ли је посреди ширење форми перцепције помоћу различитих естетских модалитета? Или је напросто пред нама велики утопијски сан као најбољи облик спознавања, јер је у њему удео стварности најмањи, а додир с невидљивим силама најнепосреднији и најпотпунији? Сигурно је само то да кроз настојање да се помере границе са људског тела које се повезује са телима животиња, али и са мртвим предметима, текстови добијају црте повећане условности, на чему Кафка нарочито инсистира. Уводећи савремене теме о телесном, о флуидној, тачније непостојећој граници између живог и предметног, хуманог и нехуманог - о чему најречитије говори фантомски лик Одрадека, који заправо и „није ништа друго до обичан комад дрвета - како се чини" поступак истиче карактер игре, иронични, пародијски, утопијски и други смисао. 
5.

Као што ђаво, летећи изнад Мадрида у Лесажовом роману Хроми gаба (1707), скида кровове града одједном, откривајући у њему нешто сасвим друго и неочекивано, наиме менталитет и дух сопственог града - Париза - у лабавој композицији неповезаних слика, тако и урбана утопија шири литерарне видике, отвара неке ведуте које иначе не бисмо приписали овом жанру. И као што Асмодеј, добри демон раскоши и лепоте, омогућава свом спасиоцу Дон Клеофасу Леандру да летећи на његовом плашту види шта се догађа испод кровова мадридских кућа, па и да, у низу истовремених, међусобно неповезаних сцена, схвати праве мотиве људских акција и њихове скривене мисли, тако и крилата мисао о књижевној йойолоіији, тражећи најпунији израз за ту пустоловину душе - увек у процесу настајања, као и сам град - остаје вибрантна и надасве отворена за нове увиде.

„Замислите, одлетео је кров изнад целе Русије, и ми смо се с целим народом нашли под отвореним небом", тим речима ће и Борис Пастернак описивати слободарски занос доктора Живага: „И нико нас не надгледа. Слобода!". Надомак остварене утопије, многима је у револуционарној Русији заиста изгледало да је пророчанска филозофија gијаматиа у праву. Изједначена са обоготвореним системом историјске истине, она нови „град сунца” није читала као књижевну утопију, већ као неку врсту ултимативног уџбеника из историје за свенародно образовање. Али ни слом реалног социјализма неће обезвредити утопију као залудну фикцију. „Двадесет први век ће бити век утопије или га неће бити“, тврдио је Андре Малро. Сан о граду никад неће бити досањан. 
Старија од свог имена, утопијска мисао је додуше ослобођена коначних одговора, али не и разлога за тумачење. Утолико пре што се, ширећи палету урбаног дускурса, а са њом и обим својих уобичајених значења - као могућност нове концептуализације појма и његове историје - утопија приметно удаљила од својих почетака. И док пословично збуњени читаоци зазиру како од наивног утопизма тако и од злокобних предсказања анти-утопије, мислиоци посвећени тумачењу утопије показују растуће интересовање за проблеме повезане са одјеком филозофских спорова. Скептични филозофи историје и писци попут Јонеска уверавају читаоце да је безнађе исто тако апсурдно као и нада. Да им, заправо, не простаје ништа друго сем наде у безнађе. И књижевност, дакако, која би то посведочила. ${ }^{33}$

Знамо: утопија понекад путује у обрнутом смеру од оног у којем је путовала у Морово доба. Тако и сама језичка употреба речи уйойија и уйойизам показује необично велику разноликост равноправних значења. Она потичу из различитих фаза и у својој примени понекад улазе у прилично нејасне спојеве. Књижевноисторијска анализа целог комплекса значења ових речи могла би, пре свега, са њиховим урбаним и социолошким појмом довести у везу различите историјске језичке слојеве. Поготово оне најстарије познате, какав је грчки полис, у коме је сфера града (државе) строго одвојена од сфере (куће, домаћинства) која припада сваком појединцу. Царство нужности и пролазности, једнако као и царство слободе и постојаности, остаје у сенци приватне сфере у којој се приватни људи осећају као независни.

33 Уп. Е. Симион, Румунски ейзистиенцијализам и евройска метиафизика, Београд, 237. 
Иако се с правом помињу Платонова Подıєвí и Калиполис као основни антички урбани модел, иако се радо издваја и Компанелин хелиополис на чијем челу је Метиафизик, свему ипак претходи Хиподамов

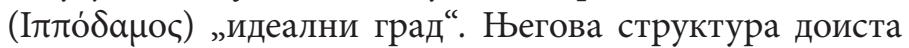
јесте полазишна тачка сваке мисли о урбаној утопији. Као артефакт разума, он није био ништа друго до основним геометријским редом изложен „секундарни систем“. Ништа друго до творевина оформљена рационализмом, бесповратно отргнута од природе и подвргнута људској контроли. Притом је, треба и то рећи, концентрација урбанитета против спољашње природе одувек имала за неизбежну последицу - стварање власти. Да иронија биде већа: проистекла из контингентног развоја, себе је представљала као природну, неумитну и непроменљиву.

Према томе се и данас одређују три основна појма утопије: интенционални, тоталитарни и хилијастички. И док је Карл Попер, на пример, разарао аутономију прва два утопијска феномена њиховом редукцијом на пуки прикључак тоталитаризма, тачније, сводећи их на његов синоним - дотле се у односу на религијску, хилијастичку пројекцију, везану са слику „небеског Јерусалима“, уочаване још веће разлике. ${ }^{34}$ Драматични и оптимистички завршетак Новог Завета надахнуо је Карла IV, великог верника и још већег мистика, да пројектује прашко Ново Место као земни одраз Новог Јерусалима - град прелеп попут невесте, чист и прозрачан као кристал, „по подобију драгог камена” (Vita Caroli).

Али оно што за утопију значи социјална критика, то је за хилијастичку парадигму - апокалипса. И овде је - с критичким повратком у прошлост - некадашња садашњост у исти мах оностраност, огромна оностраност, у којој се дубље него игде, на личан и надличан

34 V. R. Saage, ibidem, 620. 
начин, сагледају силе које управљају светом. Циљ ове парадигме није просвећивање човека кроз увид у „самоскривљене узроке“ поремећених психолошких и социјалних односа, а није ни жанровска проблематика - непрестана интерференција између утопије и анти-утопије - већ је то мобилизација индивидуалних и колективних страхова од казне Божије.

Рећи да ће с апокалипсом бити све одлучено, ${ }^{35}$ било би превише једноставно. Следећи космичку логику, смисао би се онда могао наћи у непрекидном смењивању рушења и стварања. Од одломака нашег уништеног света Бог ће створити један други свет, а после њега и наредне, и тако ће се то дешавати у бескрај. Њихова ће судбина зависити од понашања верујућих бића која ће у њима живети. Свака утопија креће од почетка, од ситуације библијског Адама. Свака понавља његову судбину - сем што је он био избачен из раја, а творци утопије из великог историјског сна.

Можемо поћи и даље: хоризонти њихових очекивања опремљени су наоко необавезујућим, а заправо неопходним атрибутом: небески. Њиховим становником се постаје да би човек био спасен, а не да би био срећнији или богатији јер поседује блага душе која му не могу бити одузета, док небески Јерусалим поприма обрисе утопије хиљадугодишњег царства утемељеног на правди и братској љубави. Парадоксално је, међутим, то што се заједно с овим разуме и једна од најпостојанијих одлика утопијског мишљења. Утопијски свет неће бити ни први ни последњи. Таква је судбина великих и малих цивилизација. Таква је, уосталом, судбина градова на земљи. Било је и других светова пре њега, а биће их након његовог коначног уништења у општем пожару или поплави која ће означити крај времена.

35 Исто, 621. 
Утопијска мисао је након 1516. године имала развој коме нема премца у новијој историји идеја. То је једини дискурс који захваљујући рефлексивности и самокритици аутора био у стању да промисли и критички реагује на сваки покрет неке нове Модерне. У том смислу је актуелност утопијске мисли очигледна, што читање таквих књига и доказује. Свеједно са којим идеолошким предзнаком су писане: небитно је да ли су их писали „рибари људских душа” или градитељи овоземаљских Вавилона.

Погрешна је претпоставка да је утопија страна генерацијама лишеним илузија, упркос чињеници да су бројни ранији утопијски модели доведени у питање. И упркос гласним тезама да имају „само” три мане: да су досадни у својој савршености, да се развијају неприродно и да се, обично, завршавају апсурдно. А најапсурдније је свакако то што до те неприродности долази због развоја природних наука.

Када такво неповерење према њима постоји, онда је оно без сумње и последица техничког напретка, иако га тај напредак, с друге стране, управо и подстиче, заједно са променама у филозофској мисли и општој интелектуалној клими. Овде је занимљиво инсистирање на томе да утопија може бити сама себи довољна, да је она апстрактни квалитет који и не мора да зависи од друштвених промена. Таласи утопијске урбофилије јављају се не само у време ратова и друштвених криза, када целокупно друштво еволуира до тога да је „дух утопије” једино што одржава заједницу, него и у периодима „високе” модерне књижевности, када господари фиктивних светова постају неимари непостојећих градова, па понекад има неслагања око тога којем жанру такве књиге, писане као својеврсни прилог теорији градске културе, уопште припадају. 
Неопозивим се ипак чини онај својеврсни слом, „докидање“ ауторитарно-етатистичког модела који припада класичној утопистичкој традицији. Али постаји друга страна медаље: са сломом реалног социјализма у Европи утопијска мисао није дискредитована, будући да актуелност проблема, који су изазвали настанак утопија од Мора наовамо, не јењава. Тако се подиже фронт поклоника људског духа, који умиру у нади да свет напредује. Парадокс је у томе што пад појединчног поретка уједно значи напредак светског процеса.

Тако се и у новом светлу вредности, у поретку који, иконокластички, оличава једна ванвременска слика града, утопија потврђује као одбојност према постојећем. То урбофилију чини и даље специфичним стањем духа и темперамента. Њена функција је да на основу утопијског тлоцрта створи нову универзалну концепцију света, надилазећи ограничене моделе осећања и атмосфере. После тога може уследити још само неко поетски-експресивно приказивање људске чежње за последњим неистраженим делићем земљиног шара, који не представља ништа друго до линије које се секу у једној тачки. Звучи апстрактно, будући да о карактеру ових промена имамо само неодређене представе. Циљ је ипак конкретан: пошто им се постојећи облици града супротстављају, утопија мора себи отворити властито подручје с ону страну посведоченог искуства.

To је подручје чежње. Подручје уздисања за местом којег (више) нема. Али највећи парадокс се састоји у томе што се у његовој највећој близини уметник налази онда када се (симболички) удаљи од свега, у првом реду од себе самог._Велики писци знају за ову своју „ману” као врлину. Они је претачу у уметност, надокнађујући на тај начин оно што су изгубили на егзистенцијалном плану: утопистички осећај испуњења. Без ње би, тврди Херман Хесе, људска душа опустела. 
Утопија је сан, али сан свестан снивања. То је нова валоризација, која је више од пуког оспоравања стварности. Реалистична, вредносна и суштински метафизичка у процени најситнијих појединости, она је и радикална ревизија социјалних активности и менталитета. Видели смо како се поновним окретањем пешчаног сата кроз који цуре зрнца утопијског песка, у једном посебном виду ретиросиекииивне утопије - која се заснива на парадоксалној нади смештеној у већ прохујалом, прошлом и само наизглед завршеном, неповратном - обликује та чежња за повратком једног урбаног света који подразумева унуйрашюе проширење, „не тек актуелно, него за слој дубље од тога”, али и сетну нејасноћу удаљености, носталгију бесконачног. У том погледу је и Бодријар несумњиво у праву када каже да не може бити речи о „крају историје”. Историја се сада може само „окренути и поновити”. И по њему се све своди на бесконачно понављање историје, на бескрајне опоравке и васпостављања. ${ }^{36}$

Све то заправо потврђују нашу основну тезу по којој и чежња постаје делокруг пророчанства. Она побија и одбацује културну „апропријацију”, као и целокупно „садашње стање”, у коме види крајњи стадијум интелектуалне апатије и културног релативизма. Увек у покрету, супротстављена принуди и догми сваке врсте, она тера сваког пророка да одушевљено изговара утопијске замисли чија порука говори сама за себе: „Треба да оставе сваку наду они који не воле утопију". Поједностављено речено: она проповеда да ће полис постати савршенији космополис.

Па ипак, у данашњем свету градска утопија представља тешко објашњиво чудо самим својим постојањем: зна се одакле је дошла, зна се који су њени

36 Jean Baudrillard, Illusions of the End, Cambridge, England: Polity Press, 1994, 103. 
пориви и каква јој је намера, али се не зна ни куда је кренула, ни који се путеви отварају пред њом, ни у име кога говори, ни када ће њен замах утихнути. Говорећи о неоправданом, „комичном” оптимизму и некој врсти надреалне небулозе, многи додуше, ишчекују њену смрт, па зато прерано најављују њену застиарелосй на начин чија иронија не остаје без публике. Но они су ретко у стању да прозру функцију савремене градског утопизма, па и сам урбани оквир за „причање приче”. Не виде да прошлост није изгубљена у маглама и тами, још мање да је то време које се понекад враћа, време које Роберто Вака, у својој познаој књизи, означава као Il medioevo prossimo venturo.

Наруку им, додуше, иду неке околности. Градска утопија модерног доба губи своје велике јунаке, велике опасности, велике перипетије и велики циљ. Фаустовски мотив - који је конститутивни идеологем утопије - потиснут је или је чак извргнут руглу. Свему се супротстављају помодни постмодерни елементи као што су историјска метафикција, смрт Великог Наратива, родне улоге, цинизам, парадокс и подражавање стилова и вредности ради извртања њиховог система изнутра. Категорија утопије и утопистичког света може се, разумљиво, сада односити само на свет појединца, на конфликт између њега и његове стварности, но тај конфликт је у специфичном свету градске утопије померен са живота и судбине на мишљење о том свету, и он се овде преобраћа у конфликт између истина за којима јунак трага и заблуда којима подлеже.

Ако, пак, у појму унтопистичког аутора не видимо неку фаталистичку категорију, већ одређени идејни квалитет писца, онда брзо пада у очи да су такви писци заправо они писци који, за главу виши од историјске свести свога времена, у своме времену готово да живе само телом, док њихова мисао, њихово осећање за 
вредности, остаје иза или испред тога времена, призивајући једну другу, историјски зрелију свест, која ће им надокнадити сву жртву неизвесности и усамљеништва.

Тиме се тежиште помера на програм решавања специфичних животних проблема који ниуколико нису наши, али с којима књижевни поступак и сам писац постају не само смисленији већ и ближи у својој понешто дон-кихотској улози спасиоца једног света који је историја већ опозвала и коме више спасења није било. Што је и ова димензија градских утопија била до сада превиђана и што је, уместо ње, у досадашњем истраживању углавном подразумеван, прећутно или отворено доказиван, тумачен, брањен и критикован један ларпурлартистички, естетицистички свет, то је опет лежало у самој природи, у самој концепцији критике.

А што је до тога уопште дошло, криво је и осећање да је савремени писац, који с нама дели судбу исте епохе, трагајући за решењима неких акутних проблема свога доба и света, природно упућен на утопистичко мишљење. Утопизам је, додуше, у нашој свести обично повезан с представама о оном што ће доћи, док писци ретроспективних утопија налазе управо супротно: да је време из којег црпе снагу неповратно прошло још за њиховог живота, и да су они сами, као „адвокати времена против времена", буднији за категорију времена, трајања и пролазности од многих данашњих тумача, несумњиво били свесни те чињенице.

Поготово се пред тешкоћама налазе покушаји да се канонизује или програмски артикулише жанр градске утопије. Као пројект без себи равна у историји песничке уметности, она зацело не ризикује да се појави као псеудо-појам. Њена је феноменологија јасна, мада се трајно излаже сумњи као варљива перспектива. Можда и као још једна тактичка диверзија анти-утопије 
саме. Према мишљењу других, утопија није чак ни идеологија, него само најнаивније од свих пророчанстава, празноверје којег су се преваранти домогли, док у књизи Уйойија и разочарење Клаудио Магрис тврди супротно и каже, не цитирајући Новалиса, да је вечни разлог путовања - повратак. Целокупна теорија романа је у романтизму ишла у том смеру. Италијански германиста се придружује реконструкцији као идеалу и као мотивацији - у изградњи и обнови једног дома, једног града, једне земље која недостаје.

А то, опет, није ништа друго до „трансцендентална топографија духа", како је ту врсту утопије назвао и Ђерђ Лукач у својој Теорији романа. То је повратак модерног Одисеја који живи у великом граду, у новом друштву које преузима грчки сан о достојанству постојања. Сада смо већ сасвим близу завршних одређења: као сценариста и редитељ ефеката које жели да постигне, рефлектујући саму себе у књижевној пракси, градска утопија остаје gелойворна, естетски интригантна, упркос непријатељски расположеном времену које, парадоксално, даје подстицај новом узлету њене теорије.

Но каква је заиста делотворност утопија, то показује историјски развој. Свако време има уйойију коју заслужује. Сваку фазу пратиле су представе које би постојећу стварност трансцендирале. А ту је већ реч о појави чија важност не може бити довољно наглашена. „Уграђене“, наиме, у одговарајућу слику света, у почетку нису деловале као утопије него као - идеологије. Тако је феудалном и црквено организованом средњовековном поретку полазило за руком да рајска обећања отклони, да их измести у оностраност, у неки вечни простор изван историје, и тако лиши сваког превратничког, револуционарног импулса. Тек каg су gрушиивене ірруие хиелеле gа буквално остиваре своје фанииазме, ове су уйойије йостиле ияеолоіије. 
На тој идејној позадини оцртавају се и ликови једног од најутицајнијих барокних драматичара, Андреаса Грифијуса (1616-1664), смерног заговорника „божанског стваралаштва”. Они увиђају да је живот на субјективно-биографском колико и на објективно-историјском плану постао недостојан живљења, те одбацивши све калупе које им је стварност понудила као могућност за реализовање властите судбине, постају добровољни „заточеници још непробуђених намера Господњих". Намерама Вишњег морају се потчинити и велики и мали, владари и убожници. Уосталом, шта је, и где је, почетак таштини (vanitas), манији величине до размера бесмртности - ако не у губитку мере, у опсесијама и фасцинацијама привидом?

Ако је уметност „смртни бог”, утопизам је његов апостол. Није стога необично што је утопијска мисао разматрала еgукайивну димензију урбане књижевности. Разлози се крију у самој суштини песништва. Jep, песништву је најпре дозвољено да нам се обрати као „нешто измишљено у одрећену сврху”, односно као „морално дозвољена обмана”, или као обмана која ствара задовољство „помоћу дозвољених средстава”. Циљ, дакле, и овде оправдава „дозвољена средства”.

Као што у животу непривлачне послове треба учинити атрактивним помоћу привидних забрана, тако и уметност мора моделовати животне радости у допадљивом облику којим ће ratio неосетно спутавати прекомерну фантазију. Свеједно да ли ће оно што је преостало бити деградирана копија реалности или уверљива визија представа у смислу да оне чине интелегибилну и укротиву „стварност”. Стога се и јавља у двострукој призми: утопијска херметичност, опојна тајанственост њене симболике и повремена непрозирност заправо су само нека врста читалачког подстицаја онима који се одваже на путовање са њеним сликама. 
Али девиза поменуте педагошке симулације „Учити кроз привид!” (Locke, 1693) одзвања у свим сферама живота и доцније, на размеђу векова. У сенци јавног урбаног васпитања остаје чак и концепт кyћної учийељь. Он траје све до краја 19. века. Његова је

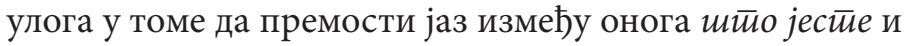

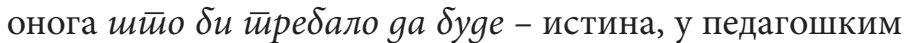
терминима поједностављених, идеалних кристализација вредности. Рецимо, као модел етичког канона, у којем се писац поставља као „морални учитељ људима”. Добро темперирану улогу „очевог заменика”, чије црте лица имитирају и његову ауторитативну строгост, успешно преузимају потом и сви они књижевни текстови у којима се одвајкада згуснуо дух утопије, обликујући педагошке идеје као да су жива бића, лични пријатељи или непријатељи.

Циљ ове парадигме је просвећивање човека кроз обликовање идеала који, пре или касније, буди веру и наду, инспирацију, велику судбину, сан о земаљској срећи. Тај сан се онда изједначава с обоготвореним системом историјске истине, те се и неизвесна будућност не чита као утопија већ као нека врста просвећеног уџбеника из историје за свенародно образовање. У томе не треба видети само страх од промашаја који нас, сви редом, као жива рана, као фаталност и клетва прате кроз историју. Ту је и отклон од радикалног песимизма филозофа, од софиста што уживају благонаклоност коју не заслужују - популарност о чијој легитимности се можемо двоумити. Свако ко отвори свој дух за овакве мисли ризикује да угледа како тоне тло на коме је подигнуто тако много утопијских градова - заједно са зидовима који су их опасали теоријом.

Хајде да признамо себи: утопијски конструкт града се може посматрати и као мистички утемељен ауйо- 


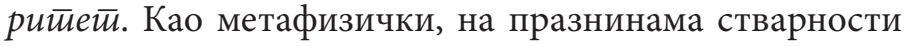
засновани утопистички простор с оне стране сваког поседовања. Он је одговоран за немогуће, за „јуриш на небо". С једне стране гледано, то заиста јесте простор који свему постојећем преокреће смисао, развлашћује свако идолопоклоничко упориште. С друге стране, међутим, у њему такође, у не мањој мери, треба видети и зазор од искушења и мобилизацију индивидуалних и колективних страхова од казне Божије. Напуштање вере притом с једне стране уопште не обезбеђује смиреност душе, као што с друге стране ниједан фанатизам не спасава ни културу ни, на фаталан начин, наду у праведнији историјски развој.

У том смислу су занимљиви и облици једног савременог феномена. Реч је о реіресивној уйойији данашњих фундаменталиста, који од система савремених друштава праве негативну личност историје, великог Сатану. Они утопију виде остварену у давној феудалној прошлости, али тај политички и цивилизцијски идеал прошлости у исти мах насилно премештају у непосредну будућност. Чак су и његове мане - предности.

Сликовито речено, они „разбијају свој сат”, газе време, попут Фокнеровог јунака. Цело биће фундаментализма је сума контрадикција, антиномија, а његов посебан модел израза заправо је провокација у односу на мишљење: то је парадоксална имагинација - насилни преображај прошлости у будућност. Али, „часовници се не подударају”, забележио је Кафка 1922. године, „унутрашњи јури ђаволски, демонски, и свакако нељудски, спољни запињући иде својим обичним ходом. Шта се може догодити сем да се та два различита света раздвоје, и они се раздвајају или се бар узајамно трзају на стравичан начин". ${ }^{37}$ У репертоару метафора које би

37 Ф. Кафка, Изабрана gела, Нолит, Београд 1978, VI, 183. 
могле да одреде антрополошку компоненту овог преображаја, мало је оних који би нам олакшали дефинисање „најбољег од свих светова”. По речима Хегела, међутим, посреди је преокретање односа између корена и крошње - „попут стабла засађеног наопако у земљу”."

Тим речима Хегел сликовито, снажније него иједним другим средством, изржава посувраћеност, унутрашњу реторзију и тегобе интимне скучености. А њима, још од памтивека, чврсто одолева један опозитни порив - анархистиччка мисао која аргументује и доказује сасвим супротно: да је субверзивни утопијски ум увек у покрету, супротстављен принуди, друштвеној аномалији, илузионизму, догми, личним интересима, свакодневној политичкој страсти. Можда не увек тако драстично као у случају Сирана де Бержерака, оног борбеног гардисте из Гаскоње, чија лунарна утопија ${ }^{39}$ буквално окреће свет наглавачке и тако најефектније раскринкава све прописане и неупитне, „вечне” истине. Седећи у раскошним кочијама, његов „путник на Месец”, приповедач у првом лицу, узвикује на свим раскршћима „Месечевог града” како „овај месец није никакав месец, него свет; и да свет тамо доле није свет, него месец".

Наравно, велико је питање да ли би сви проблеми били решени ако бисмо се приклонили буквалној контрафактури идеалног града. Поготову што нас цела легија филозофа уверава да, у духу Светог Томе, треба

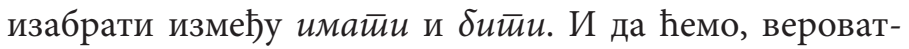
но, учинити још боље, ако се, русоовски, определимо

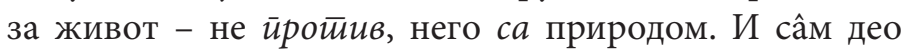
природе, град најбоље служи људском роду ако се препусти природи без прометејског пркоса. Ако се не за-

38 G. W. F. Hegel, Frühe Schriften, Frankfurt am Main, 1995, 377.

39 Cyrano de Bergerac, L'Autre monde ou les états et empires de la Lune, 1657 
почне са оваквим промишљањем, онда нико не може гарантовати шта ће бити исход. Златно доба Хесиода и доцнијих римских писаца Вергилија и Хорација било је сво у знаку узвисивања овог веровања, а остало је живо и код аутора дигиталне ере чији приповедачи се више не угледају на Кроновог божанског пастира.

Упркос критици књижевних дистопија Замјатина, Хакслија и Орвела, упркос бојазни од „кошмара будућности", овај анархистички модел социјалне утопије поседује неисцрпни потенцијал и као шира друштвена стратегија и као лични код. Са тим анархистичким моделом, сва је прилика, утопистичка мисао опробава крајње могућности своје најпоразније критике стварности. Јер она је рефлекс једног утопистичкког идеалитета који се помања на рушевинама постојећих вредности као привиђење друкчијега и бољега. У терминима идеалних кристализација вредности, на њега се надовезују тзв. „постматеријалне“ утопије шездесетих и седамдесетих година с анти-тоталитарним, феминистичким $^{40}$ и еколошким ${ }^{41}$ предзнаком једне екойойије коју су најавиле идиличне Вестич из Нuіguне Вилијема Мориса из 1889. године - понекад и с нескривеном носталгијом за примитивним културама, у којима су целокупни космолошки и морални системи изведени из ресурса изван граница реализма и рационализма.

Није само стара Грчка слављена као модел ретроспективне утопије која укључује и архајско пре-перикловско време. И није само савременим неоавангардним покретима својствена утопијска идеја о повратку у идеализовану прошлост. Према методском ритуалу који су сами себи наметнуле, свим идеологијама ус-

40 M. Piercy: Woman on the Edge of Time, 1976.

41 E. Callenbach: Ecotopia, 1975. 
мереним на изгубљене изворе чинио се занимљивим и повратак у цивилизацију Инка, у свет Полинезије и Африке, где је откривен узор за стваралаштво - мост који ће повезати савремену херметичну уметност за малобројне и друштвене масе.

Новији развој нас, међутим, учи да тај потенцијал у једнакој мери поседује и она већ описана подврста $y p$ -

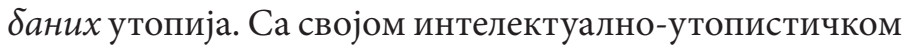
идејом о проширењу животних могућности и враћању на оно што је још растресито стање пре сваког окамењавана у данашњици, она представља, без обзира на проблематичну могућност испуњења људског и усрећења човека у 'минулој стварности', један од најсмелијих и свакако најпоетичнијих концепата за промену света у историји европске утопијске мисли.

Њихов писац наликује главном архитекти града, сетном и огорченом у исти мах, који, посматрајући његов нежељени развој, сугерише да обновимо исииорију почевши са његовим најбољим интервалом. Да сиђемо до најдужег периода мира и благостања, како бисмо исправили, на овај уистину утопистички начин, оно што је доцнија историја покварила. 